\title{
Linking the social, economic, and agroecological: a resilience framework for dairy farming
}

$\underline{\text { Nicholas A. Cradock-Henry }}^{1}$

\begin{abstract}
Agriculture is a major economic driver in Aotearoa-New Zealand (New Zealand), led by export earnings from dairy farming. Dairying is uniquely exposed to climatic- and nonclimatic socioeconomic stressors, which have their greatest effects on production and yield. The growing need to consider these and other changes is accelerating efforts aimed at ensuring greater resilience, adaptability, and flexibility within the industry. To gain insight into these dynamics at the farm-level, a resilience-based assessment framework was piloted with three different types of dairy farming systems, following extensive drought on the east coast of the North Island. Using a participatory and bottom-up approach, the framework was used to qualitatively explore the potential significance of varying social, economic, and agroecological attributes between high-input, low-input, and organic systems, and their implications for resilience. The "lock in trap" of highly intensive systems, although profitable in the near term, may be less resilient to climate shocks because these are likely to occur in conjunction with changing market and financial risks. Low-input systems are less dependent, in particular, on fossil fuels and are associated with higher levels of farmer satisfaction and well-being. Organic farming provides ecological benefits, and the financial premium paid to farmers may act as a short-term buffer. The framework provides insight into the current context at the farm level and can draw out individual perspectives on where to target interventions and build resilience. Results demonstrate the potential of in-depth qualitative assessments of resilience, which can usefully complement quantitative metrics. The framework can be used as the basis for further empirical assessment and inform the design of similar approaches for cross-sector comparative analysis, large-N surveys, or modelling. Furthermore, the preliminary characterization of resilient farm-systems has the potential to contribute to broader sustainability frameworks for agriculture and can inform strategic adaptation planning in the face of climate change.
\end{abstract}

Key Words: adaptation; agriculture; complex adaptive systems; farm systems; resilience assessment; social-ecological systems; vulnerability

\section{INTRODUCTION}

The sensitivity of pastoral farming and other agricultural activities to changes in climatic variability and extremes have been well documented (Crane et al. 2017, Cradock-Henry et al. 2019a, George et al. 2019). Higher mean temperatures, declining precipitation, and more frequent and severe storm events will have implications for human well-being, food security, and rural livelihoods (Meinke et al. 2009, Berardi et al. 2011, Rickards and Howden 2012, Cradock-Henry et al. 2020).

Climate change presents an acute challenge for Aotearoa-New Zealand (NZ) because of, in part, its dependence on agriculture (Reisinger et al. 2014, Cradock-Henry et al. 2019b). Agriculture contributes nearly $8 \%$ of annual GDP and $80 \%$ of export earnings, much of which comes from dairying (Foote et al. 2015). Short- and medium-term climate variability (Collins et al. 2010, Kenny 2011), drought (Burton and Peoples 2014, Harrington et al. 2014), and flood (Dantas and Seville 2006, Smith et al. 2011) already have adverse effects on production, farm infrastructure, and well-being (Spector et al. 2019). The increasing frequency and severity of drought, in particular, is a significant concern, exacerbated by human influence (Harrington et al. 2014, Salinger et al. 2019).

In addition to climate change, the dairy industry faces a number of social, economic, and environmental pressures (Barnett and Pauling 2005, Clark et al. 2007, Baskaran et al. 2009, Foote et al. 2015, Knook et al. 2020), from stronger controls on freshwater (Duncan 2017, Fielke and Srinivasan 2018), to its social license (Foote et al. 2015, Joy 2015), and competition from lower-cost producers (Greig et al. 2019). The industry's demographics are also changing, with a majority of farmers age 55 and over, and fewer younger farmers, discouraged by the high costs of farm ownership (Jackson 2013). Given the significance of agriculture to the national economy, and the scale of dairy and livestock farming, there is also a significant challenge for the industry to reduce its emissions, which account for nearly half of NZ's greenhouse gas contributions (Cooper and Rosin 2014).

To enable the dairy industry in NZ to adapt and thrive under changing climatic conditions, it is necessary to develop resilient systems capable of withstanding exposure to a range of shocks and stressors (Kenny 2011, Hammond et al. 2013, Spector et al. 2019). Resilience is used here to refer to a normative characteristic of linked social, economic, and agroecological systems that enable them to cope with adverse events and potentially transform to take advantage of opportunities or minimize exposure to risks (Darnhofer et al. 2010, Hammond et al. 2013, Folke et al. 2016, Cradock-Henry et al. 2018, Revell and Henderson 2019).

I introduce a conceptual framework for dairy farm resilience, emphasizing socioeconomic and agroecological factors (Kremen et al. 2012, Hammond et al. 2013). The framework is empirically applied using in-depth, semistructured interviews, surveys, and workshops to gain insight into three different farm types: intensive, high input systems; traditional, low-input, grass-based systems; and organic farms. Preliminary results can help understand the characteristics of resilience at the farm level, and the potential impacts of climate change within the broader context of other, nonclimatic stressors that may influence management and decision making. 


\section{RESILIENCE AND AGRICULTURE}

Resilience theory has been developed within a number of different research areas, including physics, psychology, natural hazards, and ecology (Miller et al. 2010, Walker and Salt 2012). The net result is that there is no universally agreed upon definition (Simmie and Martin 2010, Jones and Preston 2011); there are marked distinctions in how resilience is conceptualized because of the different disciplinary foundations used (e.g., ecology versus psychology) and even disagreement about the utility of resilience for analyzing linked human behavior and social processes (Olsson et al. 2015).

Resilience has been applied to a range of contexts, scales, and topic areas relating to agriculture and farming including climate change, adoption and innovation, behavior change, and more (Darnhofer 2010, Beilin et al. 2013, Forney and Stock 2013, Berke et al. 2015, Shadbolt and Olubode-Awosola 2016, Buelow and Cradock-Henry 2018, Fielke and Srinivasan 2018, James and Brown 2019). Many of these studies frame resilience in terms of "agroecological systems," focusing on the interactions between component parts or subsystems at the farm scale (Darnhofer 2010, Kremen et al. 2012, Hammond et al. 2013).

This study draws on two interrelated framings: social-ecological (Berkes and Jolly 2001, Adger et al. 2005, Cinner and Barnes 2019) and disaster resilience (Brown and Westaway 2011, Alexander 2013, Aldunce et al. 2015), which are used to guide conceptual development and empirical analysis. Social-ecological resilience examines the interrelationships between human activity and resource use and the impact those activities and uses have on ecological systems (Adger et al. 2005, Nayak and Berkes 2014). These human-nature interrelationships are conceptualized as coupled social-ecological systems (Berkes et al. 2008, Adger et al. 2011, Malone and Engle 2011) and describe the ways in which human activities and environmental processes are mutually dependent, coevolving, and linked through complex feedback relationships (Faulkner et al. 2018). From this perspective, farms are complex adaptive systems (Darnhofer 2010); environmental data can change is constant and must be accommodated through flexible and adaptive management (Walker and Salt 2012, Hammond et al. 2013, Li et al. 2013, Pomeroy 2015, Shadbolt and Olubode-Awosola 2016, Arnold et al. 2017). Often, this type of approach seeks to better understand the dynamics between human management of land resources and ecosystem services in the rural sector (Turner et al. 2016, Diserens et al. 2018, Smith 2019, Yletyinen et al. 2019).

Disaster resilience research considers the ways in which individuals and communities respond to risks (Brown and Westaway 2011, Alexander 2013, Spector et al. 2019). It aims to identify why some individuals, organizations, and communities are better able to prepare, adapt to, and recover from hazard events (Deppisch and Hasibovic 2013, Tanner et al. 2015). Disaster resilience has developed out of studies of human vulnerability to natural hazards and reflects a change in the problem-framing of hazards (Hewitt 2013, Fekete et al. 2014). Disaster resilience provides insight into individual, group, and organizational responses to risks, the dynamic processes of social resilience, and how it might be assessed (Berke et al. 2015, Faulkner et al. 2018, Cradock-Henry and Fountain 2019, Cradock-Henry et al. 2019c).
Despite the interest in resilience theory and practice, there are few examples of how to practically operationalize the concept for comparison. In some studies, indicators have been used to measure factors considered to be important contributors to resilience (Birkmann 2007, Alessa et al. 2008, Bélanger et al. 2012, Arnott et al. 2016). These quantitative metrics can accommodate different units of analysis, thus data related to human well-being, economic systems, and the biophysical environment can be, if not integrated, at least considered together. Studies have used mapping and other data visualization techniques to portray the results of indicator analyses (Nelson et al. 2010a, Preston et al. 2011, Ebi et al. 2018).

Indicator methods are perhaps most appropriate when comparison is desired: "Who or what is most/least vulnerable/ resilient?" Cutter et al.'s (2008) Disaster Resilience of Place (DROP) model, for example, proposes a suite of variables to assess resilience in coupled social-ecological systems, linking both human (e.g., demographic characteristics) and natural (e.g., area of wetlands) features to indicators to derive metrics for assessing and comparing resilience across different settings. For agriculture, Nelson et al. $(2010 a, b)$ developed a composite measure of vulnerability, combining multiple measures to develop a nationally applicable index for Australia, an approach also used by (Cabell and Oelofse 2012).

From a social-ecological or agroecological perspective, however, resilience is an emergent property arising from the complex interactions between systems and subsystems. Although some quantitative measures and models of resilience for agricultural systems have been developed and applied (e.g., Fletcher et al. 2006, Nelson et al. 2010a, 2010b) some argue that because resilience is abstract and multidimensional, it is unable to be measured directly (Carpenter et al. 2001, 2005, Bennett et al. 2005, Bélanger et al. 2012). The use of quantitative indicators to facilitate comparison between different regions or productive systems is desirable but subject to "wicked" issues that confront indicator use in general, including the dependence on several levels of assumptions, possible lack of important variables, colinearity, lack of accounting for feedbacks, and interactions (Birkmann 2007, Dakos et al. 2015, Arnott et al. 2016, Hallegatte and Engle 2019).

Instead, researchers and practitioners have advocated the use of place-based analysis of the vulnerabilities of social-ecological systems, and of context-dependent surrogates or proxies to infer the complex ways in which systems cope with change (Bennett et al. 2005, Carpenter et al. 2005, Bélanger et al. 2012, De Herde et al. 2019). These proxies are characteristics or features associated with resilient systems, used in lieu of measuring resilience itself, to gain insight into a system's performance, flexibility, adaptability and capacity for change (Berardi et al. 2011, Darnhofer et al. 2010, Bélanger et al. 2012, Cradock-Henry and Fountain 2019).

\section{STUDY AREA AND METHODS}

The research developed in-depth, qualitative case study analysis focusing on dairy farms in the Bay of Plenty, NZ. The goal of the empirical assessment was to design a framework for farm-level resilience and assess its utility in terms of providing insight into the dynamics of farms as complex adaptive systems (Kalaugher et al. 2013, Naylor et al. 2020). More specifically, the aim was to 
better understand differences between organic, low-input, and high-input farms, and explore the extent to which different production systems coped with region-specific stressors related to climate change.

\section{Case study setting}

The research was conducted in the Bay of Plenty Regional District (Bay of Plenty) located on the east coast of the North Island (Fig. 1). The district is one of marked socioeconomic contrasts between the increasingly urban and fast-growing west, and predominantly rural east.

Fig. 1. Bay of Plenty region, Aotearoa-New Zealand.

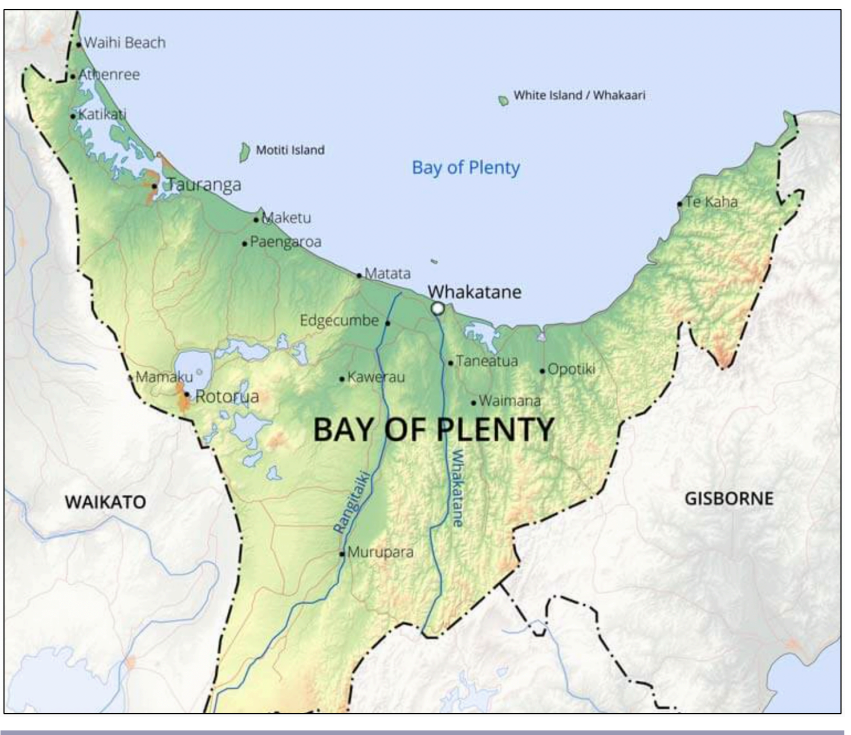

The physical environment has been shaped by earthquakes, volcanic eruption, and floods (Pullar 1985) and extensively modified for human use (Parsons and Nalau 2016). The climate is subtropical: warm humid summers and mild winters (Griffiths et al. 2011). Precipitation is seasonal, with nearly half the annual rainfall falling between May and August. Interannual climate variability is strongly influenced in the short- to medium-term by interdecadal climatic drivers (e.g., Interdecadal Pacific Oscillation, El Nino-Southern Oscillation; Fowler and Adams 2004).

Pastoral farming, i.e., dairy and livestock, is fundamental to NZ's rural economy and has supported regional development throughout the islands. The agricultural sector is largely dependent on, and connected to, global markets and economic conditions overseas (Gillmore and Briggs 2010, Gray and Le Heron 2010). This connectivity is in part a function of the reliance on exports: with a small domestic market, over 80 percent of total agricultural output is exported, some NZ\$48 billion (US\$32 billion) in 2019/20 (MPI 2020). Only 5\% of milk produced in NZ, for example, is for domestic consumption. The other distinguishing characteristic of the agricultural sector is that since the early 1980s, all state support and subsidies have been removed (Burton and Peoples 2014). New Zealand is now almost unique among developed countries in that the agricultural sector is totally exposed to international markets because subsidies, tax concessions, and price supports were eliminated (Buckle et al. 2007).
The reliance on exports dates back to the inception of the dairy industry in the late 1800s, emphasizing the export of commodities such as butter and cheese, and now milk powder. Until the 1920s, dairy exports were closely regulated through producer marketing boards; this was followed by a period of amalgamation into regional cooperatives. In 2001, the mega co-operative Fonterra was formed by the merger of two of NZ's largest cooperatives. Fonterra is now the the world's largest processor of raw milk, processing nearly 20 billion litres of milk, and the fifth largest dairy company by revenue. As a cooperative, Fonterra is owned by its 10,000 farmer-shareholders. The dairy industry in NZ remains tightly organized and vertically integrated, with farmers closely involved with the organizations that process and market dairy products, including smaller private dairy companies (Gray and Le Heron 2010).

Traditionally, NZ's seasonal milk production system has relied on highly productive, rotationally grazed pasture (Kalaugher et al. 2013, Lee et al. 2013, Foote et al. 2015), though there has been a shift in recent years toward more intensive production systems that rely more heavily on imported feeds in particular, palm kernel expeller (PKE), and maize (Table 1). Maize silage is produced domestically, and palm kernel is a low-cost by-product of palm oil production, imported from South East Asia (Meeske and van Wyngaard 2014, van Wyngaard and Meeske 2017).

Table 1. DairyNZ classification of farm systems (DairyNZ 2019).

\begin{tabular}{lll}
\hline \hline $\begin{array}{l}\text { Syst- } \\
\text { em }\end{array}$ & Definition & Description \\
\hline 1 & $\begin{array}{l}\text { All grass, self- } \\
\text { contained, all stock } \\
\text { on the dairy platform }\end{array}$ & $\begin{array}{l}\text { No feed is imported. No supplement fed to } \\
\text { the herd except supplement harvested off } \\
\text { the effective milking area and dry cows are } \\
\text { not grazed off the effective milking area. } \\
2\end{array}$ \\
$\begin{array}{l}\text { Feed imported, either } \\
\text { supplement or } \\
\text { grazing-off, for dry } \\
\text { cows }\end{array}$ & $\begin{array}{l}\text { Approx. 4-14\% of total feed is imported. } \\
\text { areas and cold climates such as Southland, } \\
\text { Feed imported to } \\
\text { extend lactation } \\
\text { (typically autumn } \\
\text { feed) and for dry } \\
\text { cows }\end{array}$ & $\begin{array}{l}\text { Approx. } 10-20 \% \text { of total feed is imported. } \\
\text { Feed to extend lactation may be imported } \\
\text { in spring rather than autumn. }\end{array}$ \\
$\begin{array}{l}\text { Feed imported and } \\
\text { used at both ends of } \\
\text { lactation and for dry } \\
\text { cows } \\
\text { Imported feed used } \\
\text { all year, throughout } \\
\text { lactation and for dry } \\
\text { cows }\end{array}$ & $\begin{array}{l}\text { Approx. 20-30\% of total feed is imported } \\
\text { onto the farm. }\end{array}$ \\
\hline
\end{tabular}

The efficiency of the grass-based system has enabled farmers to produce milk substantially below average world costs (BassetMens et al. 2009, Gray and Le Heron 2010), giving NZ dairy farmers a competitive advantage (Clark et al. 2007, Gray and Le Heron 2010, Foote et al. 2015). In response to economic pressures, changing market conditions, and government deregulation, there has been an increasing drive toward intensification (Basset-Mens et al. 2009). At the farm level, farmers have sought to create economies of scale by increasing total farm milk production through adopting more intensive grazing and feeding regimes, increasing production per hectare or increasing the number of hectares in dairy use, or both. At the milk-processing level, the 
Table 2. Summary of NZ herd statistics, 2018/2019 (LICNZ and DNZ 2019).

\begin{tabular}{lccccc}
\hline \hline Area & Herds & Total cows & $\begin{array}{c}\text { Avg. } \\
\text { herd size }\end{array}$ & Kg/milksolids/cow & Kg/milksolids/ha \\
\hline New Zealand & 11,372 & $4,946,305$ & 435 & 381 & 1081 \\
Bay of Plenty & 858 & 399,499 & 352 & 332 & 862.5 \\
\hline
\end{tabular}

sector has sought both to process all the milk it receives and to increase the value of the processed products through more sophisticated processing technologies, packaging, and marketing (Morad and Jay 1999, Gray and Le Heron 2010).

The average sizes of NZ dairy farms, herds, per cow production (through selective breeding), and the number of cows per hectare (through more intensive pasture production and pasture management) have all increased in recent decades (Macdonald et al. 2011, Kalaugher et al. 2017). Many smaller dairy units have been bought out and amalgamated to make larger units (Jay 2007, Rowarth 2013). These trends are apparent both nationally, and in the study area; farms in the study area, for which data are available, show a smaller than national average farm size, with slightly lower than average stocking rates and kilograms of milksolids production per hectare (Table 2).

The visible effects, including land-use change, water, and effluent management, have drawn considerable attention in the literature and media (Barnett and Pauling 2005, Foote et al. 2015, Kirk et al. 2017). Nonpoint pollution is a feature of farm environments, local river catchments, and river estuaries in dairying areas. These aspects are integral to overseas perceptions about farming and processing, and there are ongoing and continuing realignments of policy and investment strategies, placing greater emphasis on sustainability (Foote et al. 2015, Knook et al. 2020).

In the Bay of Plenty, dairy farming takes place throughout the region, but is concentrated on the fertile floodplains in the east, the legacy effects of wide-scale drainage in the 1900s (Parsons and Nalau 2016) and uplifted marine terraces (tablelands) also used for horticulture (Cradock-Henry 2017). Milk production varies between farms and areas because of differences in moisture availability, soil type, and management system.

\section{Research methods}

To develop a conceptual basis for empirical application and comparative assessment of dairy farm resilience, the elements of a typical dairy farm system were combined with close readings of the literature, expert elicitation, and stakeholder workshops (Fig. 2). The methodology was significantly informed by other resilience, vulnerability, and impacts assessments across a range of fields including climate change research (Berardi et al. 2011, Hammond et al. 2013, Campos et al. 2014) and environmental risks and hazards (Adger et al. 2005, Cutter et al. 2008, Darnhofer 2010, Spector et al. 2019). These were instructive in determining the choice and suitability of methods, and the potential challenges associated with participatory and practice-oriented research (Smit and Wandel 2006, Leith et al. 2012, Mapfumo et al. 2013).

The farm was initially conceptualized as a linked social-ecological system, comprised of three interrelated domains: social, economic, and agroecological, viz. a farm consists not only of the local environment, including soil and climate, but the management practices, processes, and structures necessary to achieve production outcomes (Kalaugher et al. 2013, van Apeldoorn et al. 2013, Darnohofer 2014, Harrison et al. 2017). The ecological and social components provide the basis for, and influence (and are in turn influenced by) the economic activities on the farm and in the wider environment. Ecological characteristics include favorable climatic conditions, diverse soil types (ranging from fertile peat soils through lowland areas, to some well-drained pumice soils in upland valleys), and water resources including the availability of groundwater for irrigation. Alongside this natural or biophysical capital is extensive social and economic networks and actors, including the farmers themselves, who make direct use of those resources (Beilin et al. 2013, Kalaugher et al. 2017). At higher scales, the system also includes the regional support and extension providers such as farm consultants, rural financial services, infrastructure, distribution, and processing companies across the value chain (Bélanger et al. 2012, Kalaugher et al. 2013, De Herde et al. 2019).

Fig. 2. Developing and applying the resilience framework.

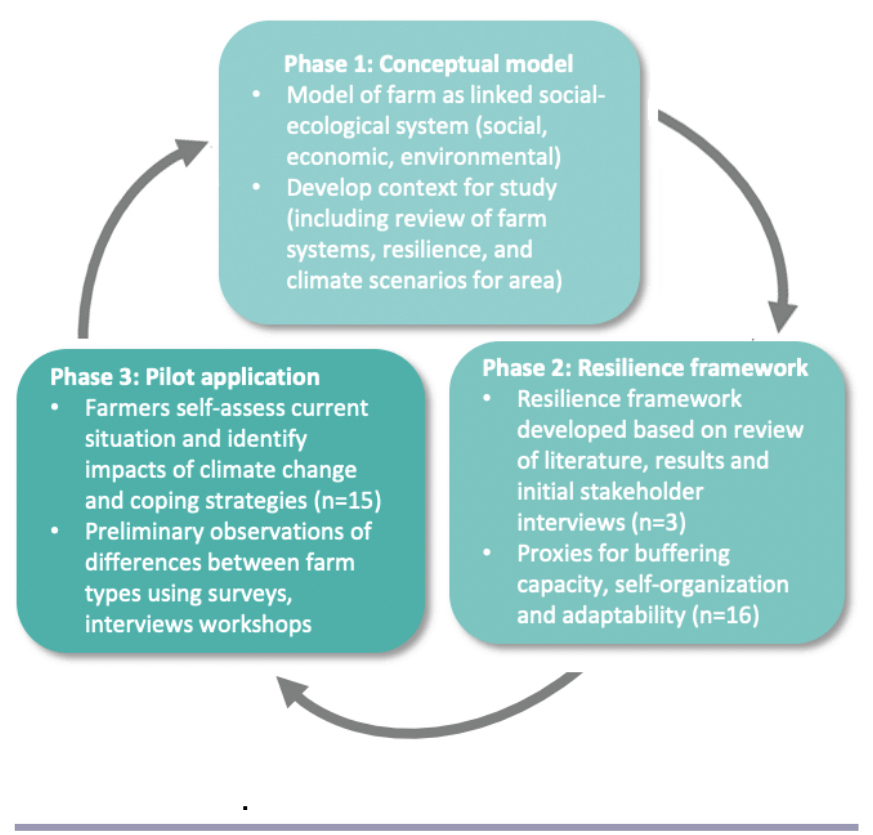

Second, a literature review of agricultural and resilience research and key informant interviews were used to identify proxies that might provide insight into the dynamics of a resilient dairy farm. A resilient dairy farm is defined here as one that is able to maintain an economically viable level of productivity in the face of localized climate change while maintaining the land's ecological integrity. 
Interviews with key informants $(n=3)$ were conducted to establish the broader national context for the dairy industry, and relevant issues at both the national and regional (Bay of Plenty) levels, and to solicit expert opinion on farmer responses to recent droughts. Key differences between types of production systems were also discussed. In addition to the farm system components, the literature on disaster risk and resilience was reviewed to better understand the significance of risk perception and its influence on planning for, and coping with, change. Assessing these typical dairy farm components against the resilience and farm-systems literature, 16 attributes of resilient farms were identified (Table 3 ). These were those characteristics and attributes of individuals and systems that could be related to the farm and would be most likely to influence the general characteristics of social-ecological resilience: buffering, adaptive capacity, and self-organization.

In preselecting the suite of farm characteristics, the following were considered in deliberations. First, the focus was on the capacity of individual dairy farms to persist or continue (i.e., maintain their identity) rather than assess the capacity for transformation (e.g., conversion from dairy to another land use or activity). Second, although the focus was at the farm scale, resilience is multiscalar, i.e., influenced by activities, actors, and actions at multiple scales (Walker et al. 2004, Choko et al. 2019). Finally, the focus was on the generic attributes of resilience or adaptive capacities, that enhance capability and capacity to respond to a range of stressors (Darnhofer et al. 2010, Folke et al. 2010) as opposed to specified resilience, which might enable farm systems to respond to a specific threat (e.g., biosecurity incursion, or invasive pest such as clover root weevil; Carpenter et al. 2012).

Finally, the model and resilience proxies were peer reviewed, then tested, and refined through qualitative case study analysis to compare conditions across farm types to gain insight into farm resilience. The qualitative methods involved interviews with 15 dairy farmers representing different production levels and 2 farmer workshops in the Bay of Plenty. The workshops were facilitated by the author; and interviews were conducted by the author and a colleague. Each interview was audio recorded and transcribed. All names were omitted from transcripts to preserve privacy, and approval was obtained prior to fieldwork, from the Social Ethics panel at Manaaki Whenua - Landcare Research.

Participants were recruited through purposive and "typical case" snowball sampling to obtain an illustrative sample of size and spatial distribution of farms. Farmers $(n=15)$ were contacted by the author and invited to take part in a structured interview and complete a survey in which they would be asked for empirical information to document the range of climate-related exposures/ sensitivities and adaptive capacities. Farms were sampled over a wide geographic area and possessed differing management systems, soil types, climate, topographic, and other biophysical characteristics (Table 4).

The survey was sent in the mail and was completed by 14 interviewees. The survey was designed to gather contextual information about individual farms (e.g., size, stocking rate), as well as concerns related to climatic conditions and the general characteristics of resilient systems (buffering, learning capacity, and self-organization). The survey used a five-point Likert scale, and respondents self-assessed key characteristics of their resilience prior to the interview. A copy of the survey questionnaire, survey results, and interview guide are available from the author on request.

Following the survey, respondents were interviewed. All the interviews followed a similar format and lasted from one to two hours. Questions were developed in advance and were designed to solicit input on a range of topics related to agricultural risk, and not climate alone (Smit and Skinner 2002, Darnhofer 2010, Miller et al. 2010, Pomeroy 2015). Interviewees were asked first about the general features of the farm (size, location, soil types, length of time in operation) and then responded to a series of questions on their experiences with the current drought, future prospects, and the farm management practices related to the characteristics of resilient systems under investigation.

Two farm resilience workshops were held. The workshops were each attended by eight people, including a mix of interviewees, other dairy farmers (often neighbors or acquaintances of those interviewed), and local government staff. The workshops were used to discuss the likely impacts of climate change on dairy farming in the Bay of Plenty, the characteristics of resilient production systems, differences between production systems and what, if any, options might exist for supporting resilience to climate change. Workshops were interactive and generated additional insight into resilience.

The methodology used is broadly consistent with analytical and methodological frameworks elsewhere (Leith et al. 2012, Liu 2014, Bronen 2015). The methodology also satisfies the criteria proposed by Schröter et al. (2005) who suggested assessments should (1) be derived on the basis of stakeholder participation, (2) be place specific, (3) consider multiple interacting stresses, (4) consider differential capacities, and (5) be prospective as well as historical.

\section{RESULTS AND DISCUSSION}

\section{Climate change impacts and dairying in the Bay of Plenty}

To gain insight into the potential impacts of climate change, information was derived from downscaled climate modeling and combined with insights from experts and stakeholders through structured interviews and workshop elicitation.

Table 5 summarizes projected changes in key climate variables for a range of dates (Griffiths et al. 2011, MFE 2018). Projections for the Bay of Plenty indicate warmer temperatures and hotter, drier conditions (MFE 2018), consistent with those predicted for much of eastern NZ (Harrington et al. 2014, Salinger et al. 2019). The Bay of Plenty warms by an average of approximately $+0.80^{\circ}$ $\mathrm{C}$ by the 2030s, and by about $+1.80^{\circ} \mathrm{C}$ by the 2080s (Griffiths et al. 2011). Changes in seasonal rainfall are predicted, while mean annual rainfall remains relatively unchanged (MFE 2018). Precipitation in NZ is strongly influenced by El Niño-Southern Oscillation (ENSO)/Interdecadal Pacific Oscillation (IPO) including variability and extremes (Harrington et al. 2016, Salinger et al. 2019). Changes in precipitation therefore will be superimposed on existing interannual and interdecadal variability.

By the 2030s, annual precipitation may decrease by as much as $15 \%$, varying seasonally from a slightly wetter winter to a much drier spring and summer. By the 2080s, the drying trend evident in the 2030s in summer and autumn will be reversed. Summer 
Table 3. Characteristics of farm-level resilience.

\begin{tabular}{l}
\hline Domain/Proxies $\quad$ Description \\
\hline Agroecological
\end{tabular}

Water security and effluent management

Soil properties and management

Stocking rate

Trees

Microclimate

Social

Attachment to place

Environmental values

Social capital

Trust in and participation with government and sector bodies

Management structure and culture

Economic

Financial resources

Profitability

Diversification

Feed security

Management practices that reduce impacts of drought Diverse local economy
Farms may secure their water supply in a number of ways and may have different levels of use for that water supply. The principal uses will be for stock water and to ensure adequate soil moisture for pasture growth. The latter may be achieved through irrigation or through farm system management (Fielke and Srinivasan 2018).

Farms with a secure and affordable water supply will be more resilient in times of drought. At the macro scale however overdependency on drawing water from rivers may reduce catchment level resilience (Walker et al. 2009).

Farmers around lakes and harbors, and with waterways through their farm, are being increasingly sensitized to runoff, sedimentation, and water quality issues. The capacity of the lakes to cope with nutrient loading will be diminished with increased lake temperatures.

Soil type will determine the underlying conditions that the farmer has to manage.

There are a number of soil properties that can be used to indicate the relative resilience of a particular soil type. These are documented in detail in Shepherd's (2009) Visual Soil Assessment.

The number of animals allocated to an area of land (i.e., cows/ha) relative to the overall carrying capacity of the farm. The stocking rate influences milk production, gross revenue, operating expenses, and operating profit (Macdonald et al. 2011). The pattern of woodlands, wetland, and individual or groves of trees within a farm system can reduce costs and provide free ecological services (e.g., shelter; shade; microclimate; soil conservation; water infiltration; landscape water retention and flood mitigation; nutrient cycling from soil depths; sediment retention; reduction in runoff of natural capital, deep-rooting droughtresistant browse; stock health; and quality stock water; England et al. 2020). In most farm situations, trees are compatible with lower production or higher risk areas under pasture, where correlated costs are high (including directed overhead costs, such as stock losses or weed control) and net margins low.

Some farms might be more vulnerable to drought than others because of microclimatic conditions that will work in combination with soil type and other agroecological factors.

Drought will impact the Bay of Plenty at the mesoscale; at the microlevel, farms may be impacted differently by, for example, late frosts, prevalent winds, etc., which might intensify or reduce macrolevel climate change impacts. Potential exposure to the effects of rising sea-levels could be included here. Impacts could include saltwater intrusion and risk of flooding and inundation (Griffiths et al. 2011, Cradock-Henry 2017).

Research has identified that having an attachment to place and to the people living in that place can increase a person's "emotional investment in their community" making them more likely to adopt adaptation measures and more likely to work collaboratively to do so (Paton 2013, Ross and Berkes 2014, Cradock-Henry et al. 2019b).

Individuals who organize environmental values high in their hierarchy may be more likely to adopt production practices that maintain ecological integrity. Managing dairy production while maintaining ecological integrity requires balancing economic and ecological outcomes. Even when people value the local environment, they also hold other values that relate to all different aspects of their lives (e.g., the value of having secure income, etc.) and people generally organize their values hierarchically (Paton 2013). Assessing a farmer's hierarchy of values could provide insights on the degree that they will adopt practices that improve ecological resilience (Sinclair et al. 2014).

Social capital describes the informal social networks and collective life of a community. Individuals tend to make sense of and explore ways to address risks in ways relevant to their specific context, through discussion with other people who share common values and circumstances with them (Ross and Berkes 2014, Aldrich and Meyer 2015). Having strong social networks facilitates these discussions.

Social capital also provides social support in times of crisis (Smith et al. 2011, Cradock-Henry et al. 2019b).

A subset of social capital (vertical social capital). If individuals trust and participate in government and sector networks, they are often more likely to accept information on climate change risks. This is especially important when they are being asked to take action to adapt in an environment of high uncertainty (Siegrist and Cvetkovich 2000).

Vertical social capital includes the degree and quality of participatory decision making between farmers, communities, and public and sector bodies, which can increase the ability for collective agreement and action on climate adaptation (Adger 2003, RodimaTaylor 2012).

The degree to which the (often complex) decision-making unit of the farm enables innovation, adaptive capacity, learning, longterm thinking, and rapid response (Berkes and Turner 2006, Fazey et al. 2007).

The availability of financial resources to buffer shocks and to facilitate drought adaptation measures. Quality of relationship with bank manager (links to social capital).

The margin on production per kilogram of milksolids. Farmers with a higher margin are more resilient to any increased costs arising from drought or adaptation investment (dependent on their debt loading).

The household is involved in other income-earning activities, off-farm (Darnhofer 2010, Kandulu et al. 2012). The diversification of income sources provides additional security.

This encompasses pasture composition and management as well as the use of supplementary feed (on-farm and imported). Different management decisions and biological processes influence feed security. Changing pasture composition (e.g., an increase in subtropical grasses such as paspalum and kikuyu) could lead to lower feed quality (Lee et al. 2013). On the other hand, it could contribute to greater drought resilience.

Pasture management practices such as longer covers can, along with appropriate soil management, lead to deeper rooting plants. Different species are more drought tolerant.

On-farm and off-farm sources of supplementary feed relate to the degree of self-organization.

Some farm management practices may be adopted specifically for drought whereas others may be adopted for other or multiple benefits. It will be important to determine if some production systems find it easier to adopt drought measures than others. Many farm households rely on off-farm income and rural communities are more resilient to economic shocks if there is diversity of local employment. 
Table 4. Distribution of farms $(n=15)$ participating in study.

\begin{tabular}{lccc}
\hline \hline Catchment & Low-input & High-input & Organic \\
\hline Tauranga Harbor & $* *$ & $*$ & $*$ \\
Rotorua Lakes & $* *$ & $*$ & \\
Te Puke & $*$ & $* *$ & \\
Rangaitaki Plains & $*$ & $* *$ & $*$ \\
Opotiki & $*$ & & \\
\hline
\end{tabular}

rainfall for the Bay of Plenty is projected to return to near the current climatology, with increased flow in the westerly winds. Autumn will also be wetter than currently by the 2080s, and winter also slightly wetter than the 2030s. Spring is expected to continue to get drier and by the 2080 s spring rainfall is projected to be about 10\% lower throughout the district (Griffiths et al. 2011).

Other changes in climatic conditions include a greater number of hot days above $25^{\circ} \mathrm{C}$ (MFE 2018) with a corresponding increase in drought frequency (Fowler and Adams 2004, Harrington et al. 2014, Salinger et al. 2019). The drying of pastures in eastern NZ in spring is very likely to be advanced by one month, with an expansion of droughts into both spring and autumn (Kenny 2011).

Mean westerly winds are expected to increase and may enhance drying trends and increase the risk of fire. By the 2080s, $10-50 \%$ more days with very high and extreme fire danger may be likely in eastern areas of NZ, including the Bay of Plenty (Pearce et al. 2011). Other changes include more intense rainfall associated with ex-tropical cyclones (Griffiths et al. 2011). Although floods are complex hydrometeorological events, the Bay of Plenty may become more prone to such heavy rainfall (Griffiths et al. 2011). This is likely to exacerbate the existing flood risk in the area, further compounded by the legacy effects of land-use change (Liu et al. 2007, Parsons and Nalau 2016).

Given these changes in key climatic variables, the focus of the analysis is on the suitability of the resilience framework and the extent to which it might usefully characterize differences between production systems. How can we better understand the resilience of different farm types: are there strengths and weaknesses, or features of different systems that can effectively support or act as a constraint on resilience?

\section{What can we learn about dairy farm resilience?}

\section{Agroecological factors}

The biophysical characteristics or attributes of any farm (e.g., microclimate, soil and substrate, terrain and altitude) influence the farm's exposure to drought, its sensitivity, and its capacity to bounce back. These biophysical factors can be tempered or enhanced by different management practices used by farmers or land managers. This includes the farm, distinguished from the surrounding environment by the manipulation of biophysical or ecological stocks, flows, and stores (e.g., water, nutrients) for milk production. It includes everything contained within the farm gate, as well as those components related to the interactions, inputs, and management of those biophysical characteristics, such as soil and pasture-management practices.

Results from workshops, interviews, and surveys indicated that water security, which includes average rainfall especially over spring and summer, on-farm reticulation, and irrigation, was most important. Rainfall varied significantly between the farms surveyed, from 1200 to $2000 \mathrm{~mm}$, within the same catchment. Those farms located in higher rainfall areas were able to withstand drought conditions much longer than even neighboring farms.

We are just high enough, so that at night we would get a good dew, and that probably kept us going a lot longer than guys down the road, who are much lower down, reported one Rotorua Lakes farmer.

In addition to annual rainfall, irrigation was understood to be a critical indicator, particularly for future water security. Of the farms surveyed, only two were currently irrigated, though nearly all respondents indicated they would consider irrigation in the future if conditions became drier. One of the farms we surveyed had a consented river take, and another nearby property irrigated $50 \%$ of the farm using a storage pond.

Other important characteristics for resilience were sustainable stocking rate, soil fertility, and soil moisture content. With respect to soils, there was considerable variation between the different farms, each with related management challenges. The majority of farmers described their soils as having low resilience to summer dry. During one farmer workshop, much of the discussion focused on farmer practices and experiences with trying to increase soil moisture capacity and fertility, often through biological means, to enhance the resilience of the pasture. Several participants had recently adopted biological farming practices in an effort to increase soil fertility, as well as to try to reduce costs. Three farmers described greater rooting depth of grass after two years of biological application and believed the biological soil management had helped preserve pasture during drought.

\section{Social factors}

As per the conceptual framework (Table 3), social attributes and characteristics of resilience of different farms were also of interest.

The suitability of the social indicators for characterizing resilience was also high. Discussion in workshops identified three social factors that were most relevant: critical awareness of potential risks, positive outcome expectancy, and self-efficacy. Critical awareness of potential risks enables an individual to be aware of a risk and assess the potential impacts exposure to that risk will have on their farm (Paton 2006, Norris et al. 2008). Positive outcome expectancy is a measure of an individual's belief that there are solutions available that will be adequate for the mitigation of that exposure (Marshall and Marshall 2007). Finally, self-efficacy is the measure of the individual's belief in their ability to carry out those solutions, to adapt (Bandura 1982). In this framing, there is a logical sequence that links the three factors: belief in the risk, belief in the solution to the risk, and belief in one's ability to implement that solution.

Based on the interviews, the majority of farmers had taken early action in response to drought conditions. This is characteristic of proactive and resilient farm decision making. In the survey, critical awareness was tested for by asking farmers to respond to a series of questions related to their understanding or knowledge of climate change and other climate-related risks. On a scale of 1-5 (very low to very high), the majority of farmers in our study ranked themselves as being medium to high. For example, several of the farmers mentioned that by early summer, despite enjoying 
Table 5. Climate change projections for the Bay of Plenty.

\begin{tabular}{|c|c|c|}
\hline \multirow[t]{2}{*}{ Climatic variable } & \multicolumn{2}{|l|}{ Data source } \\
\hline & Griffiths et al. (2011) & MFE (2018) \\
\hline Temperature $\left(\Delta\right.$ in $\left.{ }^{\circ} \mathrm{C}\right)$ & $0.80(2030), 1.80(2080)$ & $\begin{array}{l}\text { Up to } 1.1 \text { increase by } 2040 \mathrm{~s}, 0.7 \text { to } 3.1 \\
\text { warmer by } 2090 \mathrm{~s}\end{array}$ \\
\hline Summer & $0.0-1.2,0.3-3.8$ & \\
\hline Autumn & $0.1-1.3,0.4-3.9$ & $\begin{array}{l}\text { Autumn and winter warm slightly more } \\
\text { than spring and summer }\end{array}$ \\
\hline Winter & $0.4-1.6,0.8-4.2$ & \\
\hline Spring & $0.2-1.2,0.4-3.6$ & \\
\hline Precipitation $(\Delta \%$, Tauranga) & $(9)-2,(15)-2$ & $\begin{array}{l}\text { Rainfall will vary locally within the region, } \\
\text { with little change in mean annual rainfall } \\
\text { but change in seasonal patterns. }\end{array}$ \\
\hline Summer & $(10)-4,(7)-19$ & $\begin{array}{l}\text { More variable precipitation in summer and } \\
\text { autumn }\end{array}$ \\
\hline Autumn & $(16)-4,(18)-15$ & \\
\hline Winter & $(5)-7,(2)-9$ & \\
\hline Spring & $(20)-8,(41)-(3)$ & Drier spring \\
\hline Hot days $>25^{\circ} \mathrm{C}$ & & Likely increase in number of hot days \\
\hline Frost-free days & Increase in number of frost-free days & Frosts are rare by $2090 \mathrm{~s}$ \\
\hline Extreme rainfall & & \\
\hline Wind events & Increase in severe wind risk & $\begin{array}{l}\text { Up to a } 10 \% \text { increase in strong winds }(>10 \\
\mathrm{m} / \mathrm{s})\end{array}$ \\
\hline $\begin{array}{l}\text { Ex-tropical cyclones (ETCs) and } \\
\text { midlatitude storms }\end{array}$ & More intense midlatitude storms & $\begin{array}{l}\text { ETCs will likely be stronger and bring } \\
\text { heavier rainfall; increased flooding risks }\end{array}$ \\
\hline
\end{tabular}

an extremely good spring, they felt they might be in for a drought and therefore they had begun to prepare for one. One farmer, for example, observed that plants were flowering at different times, which triggered concern that they were facing a drought year. Others recognized that the weather pattern was settling into a drought in January/February and started to buy supplementary feed.

Most of the interviewees had a reasonably positive outcome expectancy that they would bounce back from the drought. For some, the rain they had received had been enough to prepare them for winter pasture, while others still needed additional substantial rainfall. Interestingly, nearly every interviewee mentioned they felt that their farm had coped better than other farms in their area.

Discussing with farmers their "critical awareness of potential risks" provided insight into beliefs about climate change. The majority of farmers surveyed, when asked about their perceptions of the risk of climate change, either did not believe that climate change was occurring, or were neutral about whether it was occurring. These results are consistent with other studies showing low critical awareness of climate change risks in other $\mathrm{NZ}$ regions (Niles and Mueller 2016).

In terms of self-efficacy, most of farmers surveyed scored themselves medium-high and the majority believed their responses to the drought were the right ones. Some farmers contrasted their personal ability to cope with the drought to the ability of their farm manager or share-milker, who were thought to have been too stressed. As one farmer said, "if you couldn't cope with the challenges of the weather, you were in the wrong profession." For older and more experienced farm owners, much of the learning to manage adverse conditions was based on previous experience. This suggests that farming requires considerable resilience at a psychological or emotional level, an ability to persevere in situations that cannot be accurately predicted or controlled, but only managed, such as drought. Previous experience with drought has aided farmers in predicting, responding effectively, and maintaining their belief that they would get through. This reflects results of other studies that show that self-efficacy is often developed through previous experiences of dealing with challenging situations, including adaptation to current climate risks (Meinke et al. 2009, Kenny 2011, Nicholas and Durham 2012, Cradock-Henry 2017, Buelow and CradockHenry 2018).

\section{Economic factors}

The third set of attributes was used to characterize economic resilience. New Zealand dairy farmers are very highly indebted, making them vulnerable to interest rate increases, a drop in land prices, and fluctuations in milk prices. A number of farmers in the study described themselves as being "asset rich" but having poor cash flow. The rise in land prices and the rapid expansion of the dairy sector have been largely funded by debt. Debt servicing can take up a large portion of farm-gate returns, limiting producers' ability to invest in on-farm improvements and lowering their overall resilience to any unexpected shocks or stresses (Greig et al. 2019).

Lower debt-equity ratios provide farmers with greater ability to borrow money in a bad year, to purchase additional feed, and "just get through" when productivity is reduced. Higher debt can reduce flexibility and make it more difficult for farmers to invest in long-term, strategic, adaptive responses.

Milk prices and compliance costs, both those of government as well as sector, were identified as influencing short-term profitability and longer-term stocking rates. Economic diversification at the household level was considered less important by the farmers we interviewed. Some farmers had deliberately diversified household and family trust investments 
Table 6. Differences in exposure to input costs (Source: Research findings).

\begin{tabular}{llcl}
\hline \hline Market exposure & Production system & Exposure & Conditions \\
\hline Rising input costs & Dairy - High Input & High & $\begin{array}{l}\text { Farmers reliant on supplemental feed or high inputs of } \\
\text { fertilizer are more exposed-sensitive to cost increases }\end{array}$ \\
& Dairy - Low input & Low & $\begin{array}{l}\text { Low-input, all grass systems reliant on fewer inputs, but } \\
\text { more sensitive to climatic conditions as they affect pasture } \\
\text { production. }\end{array}$ \\
\hline
\end{tabular}

into other sectors (e.g., commercial property) to spread risk to moderate the impact of price shocks and climactic extremes. Others had chosen to diversify into other farming activities. Of the 15 farmers interviewed, 9 had had no other income activities.

\section{How do characteristics of resilience differ between farm types?}

The second objective was to evaluate differences in farm-level resilience using the framework. Although future studies may involve large-N surveys and probabilistic, economic, or farmsystems modeling (e.g., Kalaugher et al. 2017, Buekes et al. 2019), the focus here is on the potential of the framework to characterize differences between production systems. Notwithstanding the small sample size, preliminary observations regarding features of different systems that might enable and enhance resilience across high-input, low-input, or grass-based systems and organic dairy farms are identified.

\section{High-input}

As noted earlier, there is a trend throughout NZ toward more intensive, high-input farms, with higher than average stocking rates, due to consolidation of smaller farms, rationalizing processing capacity, and the need to realize greater efficiencies. Results from the interviews and workshops show that high-input farms may be more exposed to market risks and price increases, and buffered against drought through their use of supplemental feeds. The key risks for intensive producers are their exposure to higher input costs and long-term security of feed supply (Table 6), especially when compared to low-input, grass-based systems.

Farm inputs can include labor, fertilizer, fuel, stock, seed, and materials. Additional inputs may also be related to the type of farm, the farm-management system, and the scale of the operation. There is tremendous variation as well in the scale of inputs between low- and high-input farms. The degree of resilience was correlated strongly with the management (feeding) system. High-input systems, unsurprisingly, were most sensitive. Producers also described how input costs interacted dynamically with other market forces. All agricultural input costs increased, for example, as payout to dairy farmers increased.

Within the study, the biggest determinant of sensitivity to rising input costs was the feed management system. The distinction is made here between all-grass (pasture based) or largely grass based, low-input systems, and high-input systems, which by definition, source as much $55 \%$ of animal feed from outside the farm (Basset-Mens et al. 2009, DairyNZ 2010). Typical imported feeds include maize (Stockdale 1995) and increasingly common is palm kernel expeller (PKE), a by-product from the production of palm oil (Dias et al. 2008).

Dairy farmers are paid for milksolids (per $\mathrm{kg}$ ). The actual return to dairy farmers in inflation adjusted terms has remained relatively constant and so efficiencies have to be found in the system to improve profitability (Jay 2007, Foote et al. 2015). Increased protein intake, through supplementation is one way to boost production, and supplementation was also cited by a number of dairy farmers as a way to reduce their exposure to climatic variability and extremes by decreasing their reliance on pasture growth. Recurring droughts over the last several years have resulted in an increase in the amount of supplemental feed being used by NZ dairy farmers (MPI 2015). Between 2004 and 2008, imports of PKE rose from 42,700 tonnes to over 1,000,000 tonnes (MPI 2015). Palm kernel imports for 2017/2018 exceeded 2,300,000 tonnes.

With widespread droughts in recent years, prices have risen dramatically, driven as well by global demand. Within a single season, a tonne of palm kernel landed on the farm, more than doubled in price (MPI 2015). Furthermore, these input costs are "sticky downwards;" rising quickly in response to external conditions such as a high pay-out to dairy farmers, but falling slowly, if at all.

Think about the long-term effects of this drought, said one farmer, right, grazing, for instance, is going to go up by at least fifty percent, and it's not going to go back to normal next year, is it? Palm kernel has gone from $N Z \$ 230$ to NZ\$450. You know, they give you a good pay-out, and everyone puts their costs up and then when the pay-out drops, those costs stay high and you're stuck with them. All that's happened is pay-out has gone up, but everything else has gone up too.

Finally, high-input dairy producers found themselves exposed on the supply side. During the drought, not only did feed prices rise dramatically, but feed was difficult to come by. Some farmers reported paying NZ\$200 a bale (up from NZ\$60), for "the dregs of the chest - if you can find it, because that constant supply has been a bit wayward this year."

\section{Others described maize growers running out of silage: Myneighbour, he's really upset. One of the major growers of maize around here ran out, just didn't get a good enough crop, so basically told him he couldn't have any. So that's his whole winter feed suddenly not arriving.}

By adopting a high-input system, farmers reduce their exposure to some climatic risks, buffering themselves against climate-driven effects on pasture production; however, they significantly increase their exposure to rises in input costs. These dynamics illustrate the way in which risk is transferred elsewhere in the system, but not eliminated or reduced, potentially lowering resilience of certain farming systems. The risks of a high-input system relative to a low-input one, are not unknown to producers, who identified 
increased exposure to price increases, sticky downward prices, and supply problems as concerns.

As one dairy farmer commented: To me the risk factor behind brought-in feed is horrendous. Sure, weather is our biggest risk, but there's nothing much we can do about that. But if you are high input you're very exposed to what prices do, if you're even able to get the feed in the first place.

Shifting from a low-input or all-grass system to a high-input system may increase overall production, but it is not cost-neutral. Changing management systems requires a concrete feed-pad, a dedicated tractor, and often an additional labor unit as well as the ongoing cost of PKE or maize silage. This adaptation, changing from a low to high-input system, for example, changes the nature of the system to make it better adapted to the climatic conditions but potentially increases exposure to market stresses.

At the same time, intensification may increase market risk. Anecdotally, some dairy farmers stated that milk produced from cows that are fed a highly supplemented diet, may be of lower quality with higher cell counts and water content; and one study has concluded milk from cows fed a diet high in PKE contains elevated levels of harmful transfatty acids (Benatar et al. 2011). Hence, dairy farmers are now more sensitive to market conditions as well as to conditions that effect quality, and farm income as well because payout is determined, among other things, by milk fat content (Verkerk 2003). Another market-related risk that was identified by producers, and that would indicate lower relative resilience than lower input systems, is the perception of NZ dairy products in key overseas markets.

We get a premium for our milk, and I'm not so sure that would last if everyone knew we were standing our cows on concrete and not out in the grass.

Finally, a number of farmers commented on the potential biosecurity risks associated with PKE, particularly fears of foot and mouth, which would devastate the sector.

\section{Low-input}

The results of interviews and workshops also highlighted the extent to which conventional dairy farming is relatively welladapted to current conditions. Producers using a grass-based system are more exposed/sensitive to climatic variability and extremes than those on feed-based systems. Reliance on pasture production can be mitigated in some ways through the use of supplemental feeds and a shift to higher inputs; however, this may increase exposure/sensitivity and system-dependency elsewhere in the system.

Low-input, grass-based systems (DairyNZ system 1 and 2) made up the majority of farmers interviewed. This is possibly due to the moderate climate of the Bay of Plenty region, and intensification is not as pronounced as in some other regions. Low-input farms were typically referred to by participants as "the way we've farmed this country for the last hundred years." Using the framework provides insight into both the merits and the exposures of these systems to climate change.

Low-input systems, reliant on grass growth, were most exposed to climatic conditions. There is some level of climatic risk that will be irreducible because dairy cows cannot subsist on supplemental feed alone (Verkerk 2003). In this way, drought can also be experienced at the farm level as a financial or marketrelated risk.

Producers using a low-input or all-grass system are not totally sheltered from rising input costs. The dependence on grass growth requires that soils are "adequately resourced" as some farmers put it, through the application of fertilizer, nutrients, and moisture through irrigation, to maintain production. Farmers are also exposed to any increases in electricity costs. During drought, grass-based farmers are also more sensitive to the drier weather conditions and in many cases either dried off early (i.e., stopped milking) or purchased supplementary feed to see them through. If they purchased supplement, then they were just as exposed to the rise in feed costs as others. Some low-input farms are, in fact, more exposed. If supplementary feed is required, then they may not have access through social and business networks from which to source the feed; without forward contracts, feed may be difficult to come by; and there is typically insufficient farm infrastructure (i.e., no feed pad), so wastage can be high.

For low-input producers, this problem is compounded by access. Most of the feed that was available to farmers in the last drought was absorbed by producers on high-input systems that already had forward contracts for feed purchase. As recent droughts have been more widespread, some farmers described problems with finding feed on short notice.

The problem we've had this year is that people like us, that didn't have things in place, if you like, didn't have their risk management for something like this, we couldn't source feed once it [the drought] came, because it was so widespread. The whole country was short of feed, and we just couldn't get it. Whereas some of the people that were on farms that dried every year, and had decided to manage it with feed pads, they got that feed organized before and it comes. They've been able to manage a lot better.

Low-input farmers, in general, assessed themselves better on key agroecological characteristics. Soil fertility, soil-moisture capacity, and the "engine room of the farm" was more closely monitored by farmers on grass-based systems and was a key characteristic of resilience. Some producers took a long-term view, focusing on building the buffering capacity of their soils as a strategy to mitigate against future climate. As one dairy farmer stated:

What I'm doing is creating a soil that is a buffer; that is sequestering carbon, that is healthy, and passing that down the chain. And if the sun's up there for 24 hours a day, burning a hole somewhere, it's having less effect inside my fences than anyone else's.

Low-input farmers, in general, were also more likely to be forward thinking. In short, they had fewer safety nets, limited options: "We can't just ring up and get feed," and so needed to have a longer term, strategic view. One dairy farmer ended up doing record production during the drought, an increase in yield that he attributed to closely watching all aspects of production.

When you fall in a hole, you know you're in it; whereas with monitoring you tend to know you're going to fall in a hole - try and avoid the hole. It helps knowing. 
By closely monitoring soil fertility, not only is the farm better able to withstand dry conditions, but it also has reduced their exposure to a spike in input costs.

\section{It's preventative... risk, all the things we do - whether it's fertilizer, our animal health is the same, the emphasis is on preventative care, it makes things a little bit more expensive along the way but the disasters are a lot fewer.}

When pasture growth is limited, farmers on low-input or all-grass systems must bring in supplemental feed; whereas high-input farms will adjust the ratio of pasture to supplementary feed so that stock get a greater percentage of their diet from imported foodstuffs. This can be a short-term, tactical response with farmers purchasing feed as needed; or as part of a longer-term strategy involving forward contracts or changes in farm production practices. By installing a feed pad or meal feeder system, producers have more control over feed supply, reducing exposure/sensitivity to climatic variability and extremes as they pertain to grass growth. As this dairy farmer stated:

One of the reasons people went to feed pads was because they can control their feed through the year-used to be shitloads of grass in October, November, dry out in the summer, alright in the autumn, bugger all in the winter. So you get this up and down through the season, so alright, let's feed them all year and we can control the situation and growing grass becomes a secondary thing.

There are limitations to this strategy, however. Buying supplementary feed is constrained both by farm income, only if the payout was good were producers able to make a margin, and the availability of feed. In normal drought years, this response has been adequate. Recent droughts in 2008, 2009, 2010, 2012/2013, and 2017/2018 have been far more extensive, however, covering large portions of the country (Harrington et al. 2014, Salinger et al. 2019), rendering normal adaptive strategies insufficient.

\section{Organic}

Organic dairy farms represent only a small percentage of NZs total production, and only two organic farmers participated in the study. Both organic farmers who participated said that the greatest impacts of climate change for their operations would be pasture production and animal health, and they felt they were less resilient overall to drought and future climate change compared to other farms. Unlike other farming systems, the two organic producers said they had less flexibility to respond to drought, and had to dry cows off early, resulting in lost production. The main constraint was strict rules and conditions associated with organic certification. As one farmer said, during the drought:

We could get feed, but it was coming from the Hawke's Bay and it was low on the ground... there was a tanker of [certified organic] barley in port, in Tauranga, but they'd sold it all before the ship even docked. That [organic certification] makes it really hard for us to get feed quickly when we need it. There's only so much around.

Organic producers did rate themselves highly for agroecological characteristics, particularly for soil management. Although there is considerable variation in Bay of Plenty soils at the regional and even farm scale, the two organic farmers were more familiar with their own soil types and were more inclined "to get a spade out" and inspect their soil regularly. One farmer noted that although the drought had had an impact on pasture growth, "We were able to ride out the dry a lot longer than most, and I think that was because of our soil... we've worked hard to improve it." Both farmers also noted the value of having trees on their properties for shading animals and in one case for use as an emergency fodder crop.

When surveyed, the organic farmers said they were less likely to consult with their peers about on-farm decisions and had comparatively smaller social networks than their colleagues. Part of this may simply be due to the function of the small sample, it might reflect the individualistic nature of organic producers, or because there are fewer organic farmers, they may have fewer options for peer consultation. Research elsewhere has highlighted the importance of networks for transformational adaptation (Dowd et al. 2014) and further research with a large sample would be needed to better understand the correlation, if any, between social networks, adaptation intentions, and organic farming practices (Kummer et al. 2012, Guzmán et al. 2013).

For the organic producers, rules relating to organic certification and the long lead-times required to become certified, can inhibit rapid response and limit flexibility. Climate change is likely to extend the range of subtropical invasive grasses, for example (Lee et al. 2013). However, unlike conventional farms, which can apply herbicide, these farmers noted they would need to use biological methods, which may have limited effectiveness and are expensive to apply. The increased frequency and severity of drought was also identified as a challenge. Dairy farms currently use supplemental feed to maintain production during drought, however organic farms need to be able to source certified organic feeds as a temporary measure but may be competing with other larger, nonorganic, farms, especially during widespread drought events.

Given the investment required to obtain certification, adherence to the guidelines was central to the farms' identity. Converting a farm to the required certified organic system and standards takes a minimum of three years, and profitability during that conversion is likely to be minimal.

A significant positive factor for organic producers was the premium paid by the milk company. Farmers on fully converted properties earn a NZ\$1.05 premium on each kilogram of milksolids. This premium, which was recently reviewed, ensured that at least one of the farmers interviewed managed to stay afloat during drought.

\section{As the farmer noted, Without the premium we're getting it's not worth it. I'd go to a conventional farm - but on a biological system - if we didn't get that extra.}

Nonetheless, ensuring the security of certified feed supply during drought and managing invasives are two of the biggest challenges to a more resilient organic dairy farm.

\section{CONCLUSION}

In this study of dairy farms in NZ's Bay of Plenty region, a resilience-based framework was developed and applied to gain insight into the dynamics of farm-level responses to climatic extremes. Evidence of a range of responses employed to cope with 
environmental, market, and other stresses was found. The framework, and the proxies for social, economic, and agroecological resilience, was sensitive to the differences between organic, low- and high-input farm types, and provided insight into the ways each are differentially affected by drought. For the most part, all farms seek to maintain production where possible, through the use of supplemental feed or forage, but may be constrained by costs or regulatory requirements in the case of organic farmers. Most of the strategies employed are short-term, reactive, and able to cope with interannual variability, but may not be sufficient for long-term changes

The conceptual framework provides an initial assessment of farmlevel resilience, in which qualitative information is derived from stakeholders. The framework includes proxies for assessing farmlevel resilience, which although subjective, might form the basis for further development, composite indicators, or additional empirical examples. Indicators for resilience remain an active area of research internationally. Quantitative metrics are not without their limitations, however they may be able to facilitate larger studies, comparative analysis at the regional scale, and quantify the costs-and-benefits associated with each farm type, more robustly. The framework, furthermore, has not considered potential for identifying win-wins, for example, that provide adaptation benefits while also reducing a farm's greenhouse gas emissions. Given NZ's unique emissions profile and the need for farm to meet multiple objectives (including freshwater standards), resilience-based metrics may be desirable.

The current study was also limited by the small sample size, and future work could scale the analysis to consider a larger area, as well as assess its versatility for use in other primary industries. Many of the proxies identified are relevant for other industries. For example, recent work on resilience in the wine industry used a model of resilience to characterize a stability landscape (Cradock-Henry and Fountain 2019), which could be combined with proxy indicators developed here for more detailed analysis. Finally, the proxies might also be used in other processes, or as input to decision-support systems, to help identify critical decision thresholds or triggers (Yletyinen et al. 2019).

As the impacts of climate change accelerate, it will be necessary to closely monitor the ways in which farms and agricultural sectors adapt. Regardless of how the future unfolds, the resilience of the dairy industry is likely to be watched with interest, given its prominence. Enhancing dairy farming's resilience through innovative and sustainable practices can help showcase adaptation options for other sectors in anticipation of future changes.

Responses to this article can be read online at: https://www.ecologyandsociety.org/issues/responses. php/12122

\section{Acknowledgments:}

This work was supported through the Ministry for Primary Industries' Sustainable Land Management and Climate Change (SLMACC) fund and Resilience to Nature's Challenges National
Science Challenge. Special thanks to Claire Mortimer (MBIE) for assisting with the original interviews and analysis. We gratefully acknowledge the support of interviewees and workshop participants who generously contributed their time and insights. Thank you also to the anonymous reviewers whose feedback has helped improve the manuscript.

\section{Data Availability:}

Survey questionnaire, survey results, and supporting materials are available from the author upon request.

\section{LITERATURE CITED}

Adger, W. N. 2003. Social capital, collective action, and adaptation to climate change. Economic Geography 79 (4):387-404.

Adger, W. N., K. Brown, D. R. Nelson, F. Berkes, H. Eakin, C. Folke, K. Galvin, L. Gunderson, M. Goulden, K. O’Brien, J. Ruitenbeek, and E. L. Tompkins. 2011. Resilience implications of policy responses to climate change. Wiley Interdisciplinary Reviews: Climate Change 2(5):757-766. https://doi.org/10.1002/ wcc. 133

Adger, W. N., T. P. Hughes, C. Folke, S. R. Carpenter, and J. Rockström. 2005. Social-ecological resilience to coastal disasters. Science 309(5737):1036-1039. https://doi.org/10.1126/science.1112122

Aldrich, D. P., and M. A. Meyer. 2015. Social capital and community resilience. American Behavioral Scientist 59 (2):254-269. https://doi.org/10.1177/0002764214550299

Aldunce, P., R. Beilin, M. Howden, and J. Handmer. 2015. Resilience for disaster risk management in a changing climate: practitioners' frames and practices. Global Environmental Change 30:1-11. https://doi.org/10.1016/j.gloenvcha.2014.10.010

Alessa, L., A. Kliskey, R. Lammers, C. Arp, D. White, L. Hinzman, and R. Busey. 2008. The Arctic water resource vulnerability index: an integrated assessment tool for community resilience and vulnerability with respect to freshwater. Environmental Management 42(3):523. https://doi.org/10.1007/ s00267-008-9152-0

Alexander, D. E. 2013. Resilience and disaster risk reduction: an etymological journey. Natural Hazards and Earth System Science 13(11):2707-2716. https://doi.org/10.5194/nhess-13-2707-2013

Arnold, C. A., H. Gosnell, M. H. Benson, and R. K. Craig. 2017. Cross-interdisciplinary insights into adaptive governance and resilience. Ecology and Society 22(4):14. https://doi.org/10.5751/ ES-09734-220414

Arnott, J. C., S. C. Moser, and K. A. Goodrich. 2016. Evaluation that counts: a review of climate change adaptation indicators and metrics using lessons from effective evaluation and sciencepractice interaction. Environmental Science and Policy 66:383-392. https://doi.org/10.1016/j.envsci.2016.06.017

Bandura, A. 1982. Self-efficacy mechanism in human agency. American Psychologist 37(2):122-147. https://doi. org/10.1037/0003-066X.37.2.122 
Barnett, J., and J. Pauling. 2005. The environmental effects of New Zealand's free-market reforms. Environment, Development and Sustainability 7(2):271-289. https://doi.org/10.1007/s10668-005-7316-0

Baskaran, R., R. Cullen, and S. Colombo. 2009. Estimating values of environmental impacts of dairy farming in New Zealand. New Zealand Journal of Agricultural Research 52(4):377-389. https:// doi.org/10.1080/00288230909510520

Basset-Mens, C., S. Ledgard, and M. Boyes. 2009. Eco-efficiency of intensification scenarios for milk production in New Zealand. Ecological Economics 68(6):1615-1625. https://doi.org/10.1016/j. ecolecon.2007.11.017

Beilin, R., N. T. Reichelt, B. J. King, A. Long, and S. Cam. 2013. Transition landscapes and social networks: examining on-ground community resilience and its implications for policy settings in multiscalar systems. Ecology and Society 18(2):30. https://doi. org/10.5751/ES-05360-180230

Bélanger, V., A. Vanasse, D. Parent, G. Allard, and D. Pellerin. 2012. Development of agri-environmental indicators to assess dairy farm sustainability in Quebec, Eastern Canada. Ecological Indicators 23:421-430. https://doi.org/10.1016/i.ecolind.2012.04.027

Benatar, J. R., P. Gladding, H. D. White, I. Zeng, and R. A. H. Stewart. 2011. Trans-fatty acids in New Zealand patients with coronary artery disease. European Journal of Cardiovascular Prevention and Rehabilitation 18(4):615-620. https://doi. org/10.1177/1741826710389415

Bennett, E. M., G. S. Cumming, and G. D. Peterson. 2005. A systems model approach to determining resilience surrogates for case studies. Ecosystems 8(8):945-957. https://doi.org/10.1007/ s10021-005-0141-3

Berardi, G., R. Green, and B. Hammond. 2011. Stability, sustainability, and catastrophe: applying resilience thinking to U. S. agriculture. Human Ecology Review 18(2):115-125. [online] URL: https://www.humanecologyreview.org/pastissues/her182/ berardi.pdf

Berke, P., G. Newman, J. Lee, T. Combs, C. Kolosna, and D. Salvesen. 2015. Evaluation of networks of plans and vulnerability to hazards and climate change: a resilience scorecard. Journal of the American Planning Association 81(4):287-302. https://doi. org/10.1080/01944363.2015.1093954

Berkes, F., J. Colding, and C. Folke, editors. 2008. Navigating social-ecological systems: building resilience for complexity and change. Cambridge University Press, Cambridge, UK. https://doi. org/10.1017/CBO9780511541957

Berkes, F., and D. Jolly. 2001. Adapting to climate change: socialecological resilience in a Canadian Western Arctic community. Conservation Ecology 5(2):18. https://doi.org/10.5751/ES-00342-050218

Berkes, F., and N. J. Turner. 2006. Knowledge, learning and the evolution of conservation practice for social-ecological system resilience. Human Ecology 34(4):479-494. https://doi.org/10.1007/ s10745-006-9008-2

Beukes, P. C., A. J. Romera, M. Neal, and K. Mashlan. 2019. Performance of pasture-based dairy systems subject to economic, climatic and regulatory uncertainty. Agricultural Systems 174:95-104. https://doi.org/10.1016/j.agsy.2019.05.002

Birkmann, J. 2007. Risk and vulnerability indicators at different scales: applicability, usefulness and policy implications. Environmental Hazards 7(1):20-31. https://doi.org/10.1016/j. envhaz.2007.04.002

Bronen, R. 2015. Climate-induced community relocations: using integrated social-ecological assessments to foster adaptation and resilience. Ecology and Society 20(3):36. https://doi.org/10.5751/ ES-07801-200336

Brown, K., and E. Westaway. 2011. Agency, capacity, and resilience to environmental change: lessons from human development, well-being, and disasters. Annual Review of Environment and Resources 36(1):321-342. https://doi.org/10.1146/ annurev-environ-052610-092905

Buckle, R. A., K. Kim, H. Kirkham, N. McLellan, and J. Sharma. 2007. A structural VAR business cycle model for a volatile small open economy. Economic Modelling 24(6):990-1017. https://doi. org/10.1016/i.econmod.2007.04.003

Buelow, F., and N. Cradock-Henry. 2018. What you sow is what you reap? (Dis-)incentives for adaptation intentions in farming. Sustainability 10(4):1133. https://doi.org/10.3390/su10041133

Burton, R. J. F., and S. Peoples. 2014. Market liberalisation and drought in New Zealand: a case of 'double exposure' for dryland sheep farmers? Journal of Rural Studies 33:82-94. https://doi org/10.1016/i.jrurstud.2013.11.002

Cabell, J., and M. Oelofse. 2012. An indicator framework for assessing agroecosystem resilience. Ecology and Society 17(1):18. https://doi.org/10.5751/ES-04666-170118

Campos, M., A. Velázquez, and M. McCall. 2014. Adaptation strategies to climatic variability: a case study of small-scale farmers in rural Mexico. Land Use Policy 38:533-540. https://doi. org/10.1016/j.landusepol.2013.12.017

Carpenter, S. R., K. J. Arrow, S. Barrett, R. Biggs, W. A. Brock, A.-S. Crépin, G. Engström, C. Folke, T. P. Hughes, N. Kautsky, C.-Z. Li, G. McCarney, K. Meng, K.-G. Mäler, S. Polasky, M. Scheffer, J. Shogren, T. Sterner, J. R. Vincent, B. Walker, A. Xepapadeas, and A. De Zeeuw. 2012. General resilience to cope with extreme events. Sustainability 4(12):3248-3259. https://doi. org/10.3390/su4123248

Carpenter, S., B. Walker, J. M. Anderies, and N. Abel. 2001. From metaphor to measurement: resilience of what to what? Ecosystems 4(8):765-781. https://doi.org/10.1007/s10021-001-0045-9

Carpenter, S. R., F. Westley, and M. G. Turner. 2005. Surrogates for resilience of social-ecological systems. Ecosystems 8 (8):941-944. https://doi.org/10.1007/s10021-005-0170-y

Choko, O. P., L. Schmitt Olabisi, R. U. Onyeneke, S. N. Chiemela, L. S. O. Liverpool-Tasie, and L. Rivers III. 2019. A resilience approach to community-scale climate adaptation. Sustainability 11(11):3100. https://doi.org/10.3390/su11113100

Cinner, J. E., and M. L. Barnes. 2019. Social dimensions of resilience in social-ecological systems. One Earth 1(1):51-56. https://doi.org/10.1016/j.oneear.2019.08.003 
Clark, D. A., J. R. Caradus, R. M. Monaghan, P. Sharp, and B. S. Thorrold. 2007. Issues and options for future dairy farming in New Zealand. New Zealand Journal of Agricultural Research 50 (2):203-221. https://doi.org/10.1080/00288230709510291

Collins, M., S.-I. An, W. Cai, A. Ganachaud, E. Guilyardi, F.-F. Jin, M. Jochum, M. Lengaigne, S. Power, A. Timmermann, G. Vecchi, and A. Wittenberg. 2010. The impact of global warming on the tropical Pacific Ocean and El Niño. Nature Geoscience 3 (6):391-397. https://doi.org/10.1038/ngeo868

Cooper, M. H., and C. Rosin. 2014. Absolving the sins of emission: the politics of regulating agricultural greenhouse gas emissions in New Zealand. Journal of Rural Studies 36:391-400. https://doi.org/10.1016/j.jrurstud.2014.06.008

Cradock-Henry, N. A. 2017. New Zealand kiwifruit growers' vulnerability to climate and other stressors. Regional Environmental Change 17(1):245-259. https://doi.org/10.1007/ s10113-016-1000-9

Cradock-Henry, N. A., P. Blackett, M. Hall, P. Johnstone, E. Teixeira, and A. Wreford. 2020. Climate adaptation pathways for agriculture: insights from a participatory process. Environmental Science and Policy 107:66-79. https://doi.org/10.1016/j.envsci.2020.02.020

Cradock-Henry, N. A., F. Buelow, S. Flood, P. Blackett, and A. Wreford. 2019a. Towards a heuristic for assessing adaptation knowledge: impacts, implications, decisions and actions. Environmental Research Letters 14(9):093002. https://doi. org/10.1088/1748-9326/ab370c

Cradock-Henry, N. A., F. Buelow, and J. Fountain. 2019b. Socialecological inventory in a postdisaster context: the 2016 Kaikôura earthquake, Aotearoa-New Zealand. Ecology and Society 24(3):9. https://doi.org/10.5751/es-11075-240309

Cradock-Henry, N. A., S. Flood, F. Buelow, P. Blackett, and A. Wreford. 2019a. Adaptation knowledge for New Zealand's primary industries: known, not known and needed. Climate Risk Management 25:100190. https://doi.org/10.1016/j.crm.2019.100190

Cradock-Henry, N. A., and J. Fountain. 2019. Characterising resilience in the wine industry: insights and evidence from Marlborough, New Zealand. Environmental Science and Policy 94:182-190. https://doi.org/10.1016/j.envsci.2019.01.015

Cradock-Henry, N. A., J. Fountain, and F. Buelow. 2018. Transformations for resilient rural futures: the case of Kaikôura, Aotearoa-New Zealand. Sustainability 10(6):1952. https://doi. org/10.3390/su10061952

Crane, T. A., A. Delaney, P. A. Tamás, S. Chesterman, and P. Ericksen. 2017. A systematic review of local vulnerability to climate change in developing country agriculture. Wiley Interdisciplinary Reviews: Climate Change 8(4):e464. https://doi. org/10.1002/wcc.464

Cutter, S. L., L. Barnes, M. Berry, C. Burton, E. Evans, E. Tate, and J. Webb. 2008. A place-based model for understanding community resilience to natural disasters. Global Environmental Change 18(4):598-606. https://doi.org/10.1016/j.gloenvcha.2008.07.013
DairyNZ. 2021. The 5 production systems. DairyNZ, Hamilton, New Zealand. [online] URL: https://www.dairynz.co.nz/business/ the-5-production-systems/

Dakos, V., S. R. Carpenter, E. H. van Nes, and M. Scheffer. 2015. Resilience indicators: prospects and limitations for early warnings of regime shifts. Philosophical Transactions of the Royal Society B: Biological Sciences 370(1659):20130263. https://doi. org/10.1098/rstb.2013.0263

Dantas, A., and E. Seville. 2006. Organisational Issues in implementing an information sharing framework: lessons from the Matata flooding events in New Zealand. Journal of Contingencies and Crisis Management 14(1):38-52. https://doi. org/10.1111/j.1468-5973.2006.00479.x

Darnhofer, I. 2010. Strategies of family farms to strengthen their resilience. Environmental Policy and Governance 20(4):212-222. https://doi.org/10.1002/eet.547

Darnhofer, I. 2014. Resilience and why it matters for farm management. European Review of Agricultural Economics 41 (3):461-484. https://doi.org/10.1093/erae/jbu012

Darnhofer, I., S. Bellon, B. Dedieu, and R. Milestad. 2010a. Adaptiveness to enhance the sustainability of farming systems. A review. Agronomy for Sustainable Development 30:545-555. https://doi.org/10.1051/agro/2009053

Darnhofer, I., J. Fairweather, and H. Moller. 2010b. Assessing a farm's sustainability: insights from resilience thinking. International Journal of Agricultural Sustainability 8(3):186-198.

De Herde, V., K. Maréchal, and P. V. Baret. 2019. Lock-ins and agency: towards an embedded approach of individual pathways in the Walloon dairy sector. Sustainability 11(16):4405. https:// doi.org/10.3390/su11164405

Deppisch, S., and S. Hasibovic. 2013. Social-ecological resilience thinking as a bridging concept in transdisciplinary research on climate-change adaptation. Natural Hazards 67(1):117-127. https://doi.org/10.1007/s11069-011-9821-9

Dias, F. N., J. L. Burke, D. Pacheco, and C. W. Holmes. 2008. The effect of palm kernel expeller as a supplement for grazing dairy cows at the end of lactation. Proceedings of the New Zealand Society of Animal Production 68:111-112.

Diserens, F., J. M. H. Choptiany, D. Barjolle, B. Graeub, C. Durand, and J. Six. 2018. Resilience assessment of Swiss farming systems: piloting the SHARP-tool in Vaud. Sustainability 10 (12):4435. https://doi.org/10.3390/su10124435

Dowd, A.-M., N. Marshall, A. Fleming, E. Jakku, E. Gaillard, and M. Howden. 2014. The role of networks in transforming Australian agriculture. Nature Climate Change 4(7):558-563. https://doi.org/10.1038/nclimate2275

Duncan, R. 2017. The challenges of regulating diffuse agricultural pollution to improve water quality: a science policy perspective on approaches to setting enforceable catchment load limits in New Zealand. Case Studies in the Environment 1:1-7. https://doi.org/10.1525/cse.2017.sc.433549 
Ebi, K. L., C. Boyer, K. J. Bowen, H. Frumkin, and J. Hess. 2018. Monitoring and evaluation indicators for climate change-related health impacts, risks, adaptation, and resilience. International Journal of Environmental Research and Public Health 15(9):1943. https://doi.org/10.3390/ijerph15091943

England, J. R., A. P. O'Grady, A. Fleming, Z. Marais, and D. Mendham. 2020. Trees on farms to support natural capital: an evidence-based review for grazed dairy systems. Science of the Total Environment 704:135345. https://doi.org/10.1016/j. $\underline{\text { scitotenv.2019.135345 }}$

Faulkner, L., K. Brown, and T. Quinn. 2018. Analyzing community resilience as an emergent property of dynamic socialecological systems. Ecology and Society 23(1):24. https://doi. org/10.5751/ES-09784-230124

Fazey, I., J. A. Fazey, J. Fischer, K. Sherren, J. Warren, R. F. Noss, and S. R. Dovers. 2007. Adaptive capacity and learning to learn as leverage for social-ecological resilience. Frontiers in Ecology and the Environment 5(7):375-380. https://doi.org/10.1890/1540-9295 (2007)5[375:acalt1]2.0.co;2

Fekete, A., G. Hufschmidt, and S. Kruse. 2014. Benefits and challenges of resilience and vulnerability for disaster risk management. International Journal of Disaster Risk Science 5 (1):3-20. https://doi.org/10.1007/s13753-014-0008-3

Fielke, S. J., and M. S. Srinivasan. 2018. Co-innovation to increase community resilience: influencing irrigation efficiency in the Waimakariri Irrigation Scheme. Sustainability Science 13 (1):255-267. https://doi.org/10.1007/s11625-017-0432-6

Fletcher, C. S., M. Craig, and D. W. Hilbert. 2006. Operationalizing resilience in Australian and New Zealand agroecosystems. Proceedings of the 50th annual meeting of the ISSS - 2006, Sonoma, CA, USA. International Society for the Systems Sciences. [online] URL: https://journals.isss.org/index. php/proceedings50th/article/view/355

Folke, C., R. Biggs, A. V. Norström, B. Reyers, and J. Rockström. 2016. Social-ecological resilience and biosphere-based sustainability science. Ecology and Society 21(3):41. https://doi.org/10.5751/ ES-08748-210341

Folke, C., S. R. Carpenter, B. Walker, M. Scheffer, T. Chapin, and J. Rockström. 2010. Resilience thinking: integrating resilience, adaptability, and transformability. Ecology and Society 15(4):20. https://doi.org/10.5751/ES-03610-150420

Foote, K. J., M. K. Joy, and R. G. Death. 2015. New Zealand dairy farming: milking our environment for all its worth. Environmental Management 56(3):709-720. https://doi.org/10.1007/ $\underline{\text { s00267-015-0517-X }}$

Forney, J., and P. V. Stock. 2013. Conversion of family farms and resilience in Southland, New Zealand. International Journal of Sociology of Agriculture and Food 21(1):7-29.

Fowler, A., and K. Adams. 2004. Twentieth century droughts and wet periods in Auckland (New Zealand) and their relationship to ENSO. International Journal of Climatology 24(15):1947-1961. https://doi.org/10.1002/joc. 1100

George, D. A., J. F. Clewett, D. Lloyd, R. McKellar, P.-L. Tan, M. Howden, L. Rickards, D. Ugalde, and S. Barlow. 2019.
Research priorities and best practices for managing climate risk and climate change adaptation in Australian agriculture. Australasian Journal of Environmental Management 26(1):6-24. https://doi.org/10.1080/14486563.2018.1506948

Gillmore, D., and P. Briggs. 2010. World trade interdependencies: a New Zealand perspective. Reserve Bank of New Zealand: Bulletin 73(2):35-46. [online] URL: https://www.rbnz.govt.nz/-/ media/ReserveBank/Files/Publications/Bulletins/2010/2010jun73-2gillmorebriggs.pdf

Gray, S., and R. Le Heron. 2010. Globalising New Zealand: Fonterra Co-operative Group, and shaping the future. New Zealand Geographer 66(1):1-13. https://doi.org/10.1111/ j.1745-7939.2010.01173.x

Greig, B., P. Nuthall, and K. Old. 2019. Resilience and finances on Aotearoa New Zealand farms: evidence from a random survey on the sources and uses of debt. New Zealand Geographer 75 (1):21-33. https://doi.org/10.1111/nzg.12207

Griffiths, F., B. Mullan, D. Ackerley, A. Sood, T. Carey-Smith, L. Wilcocks, and J. Sturman. 2011. An updated climate change assessment for the Bay of Plenty. NIWA, Auckland, New Zealand. [online] URL: https://www.smartgrowthbop.org.nz/media/1137/ h-an_updated_climate change assessment for the bay of plenty 13 december 2011.pdf

Guzmán, G. I., D. López, L. Román, and A. M. Alonso. 2013. Participatory action research in agroecology: building local organic food networks in Spain. Agroecology and Sustainable Food Systems 37(1):127-146. https://doi.org/10.1080/10440046.2012.718997

Hallegatte, S., and N. L. Engle. 2019. The search for the perfect indicator: reflections on monitoring and evaluation of resilience for improved climate risk management. Climate Risk Management 23:1-6. https://doi.org/10.1016/j.crm.2018.12.001

Hammond, B., G. Berardi, and R. Green. 2013. Resilience in agriculture: small- and medium-sized farms in Northwest Washington State. Agroecology and Sustainable Food Systems 37 (3):316-339. https://doi.org/10.1080/10440046.2012.746251

Harrington, L. J., P. B. Gibson, S. M. Dean, D. Mitchell, S. M. Rosier, and D. J. Frame. 2016. Investigating event-specific drought attribution using self-organizing maps. Journal of Geophysical Research: Atmospheres 121(21):12,766-12,780. https://doi. org/10.1002/2016JD025602

Harrington, L. J., S. Rosier, S. M. Dean, S. Stuart, and A. Scahill. 2014. The role of anthropogenic climate change in the 2013 drought over North Island, New Zealand. Explaining Extremes of 2013 from a Climate Perspective, Special Supplement of the Bulletin of the American Meteorological Society 95(9):S45-S48.

Harrison, M. T., B. R. Cullen, and D. Armstrong. 2017. Management options for dairy farms under climate change: effects of intensification, adaptation and simplification on pastures, milk production and profitability. Agricultural Systems 155:19-32. https://doi.org/10.1016/j.agsy.2017.04.003

Hewitt, K. 2013. Environmental disasters in social context: toward a preventive and precautionary approach. Natural Hazards 66(1):3-14. https://doi.org/10.1007/s11069-012-0205-6 
Jackson, N. 2013. Demographic change in New Zealand's dairy farming industry: the need for a cohort perspective. New Zealand Population Review 39:77-99. [online] URL: https://www. hidropolitikakademi.org/uploads/wp/2017/04/Demographic-changesin-new-zellands-diary-farming-.pdf

James, T., and K. Brown. 2019. Muck and magic: a resilience lens on organic conversions as transformation. Society and Natural Resources 32(2):133-149. https://doi.org/10.1080/08941920.2018.1506069

Jay, M. 2007. The political economy of a productivist agriculture: New Zealand dairy discourses. Food Policy 32(2):266-279. https:// doi.org/10.1016/j.foodpol.2006.09.002

Jones, R. N., and B. L. Preston. 2011. Adaptation and risk management. Wiley Interdisciplinary Reviews: Climate Change 2 (2):296-308. https://doi.org/10.1002/wcc.97

Joy, M. 2015. Polluted inheritance: New Zealand's freshwater crisis. Bridget Williams, Wellington, New Zealand. https://doi. org/10.7810/9780908321612 2

Kalaugher, E., P. Beukes, J. F. Bornman, A. Clark, and D. I. Campbell. 2017. Modelling farm-level adaptation of temperate, pasture-based dairy farms to climate change. Agricultural Systems 153:53-68. https://doi.org/10.1016/j.agsy.2017.01.008

Kalaugher, E., J. F. Bornman, A. Clark, and P. Beukes. 2013. An integrated biophysical and socio-economic framework for analysis of climate change adaptation strategies: the case of a New Zealand dairy farming system. Environmental Modelling and Software 39:176-187. https://doi.org/10.1016/j.envsoft.2012.03.018

Kandulu, J. M., B. A. Bryan, D. King, and J. D. Connor. 2012. Mitigating economic risk from climate variability in rain-fed agriculture through enterprise mix diversification. Ecological Economics 79:105-112. https://doi.org/10.1016/j.ecolecon.2012.04.025

Kenny, G. 2011. Adaptation in agriculture: lessons for resilience from eastern regions of New Zealand. Climatic Change 106 (3):441-462. https://doi.org/10.1007/s10584-010-9948-9

Kirk, N., A. Brower, and R. Duncan. 2017. New public management and collaboration in Canterbury, New Zealand's freshwater management. Land Use Policy 65:53-61. https://doi. org/10.1016/j.landusepol.2017.03.034

Knook, J., R. Dynes, I. Pinxterhuis, C. A. M. de Klein, V. Eory, M. Brander, and D. Moran. 2020. Policy and practice certainty for effective uptake of diffuse pollution practices in a light-touch regulated country. Environmental Management 65(2):243-256. https://doi.org/10.1007/s00267-019-01242-y

Kremen, C., A. Iles, and C. Bacon. 2012. Diversified farming systems: an agroecological, systems-based alternative to modern industrial agriculture. Ecology and Society 17(4):44. https://doi. org/10.5751/ES-05103-170444

Kummer, S., R. Milestad, F. Leitgeb, and C. Vogl. 2012. Building resilience through farmers' experiments in organic agriculture: examples from Eastern Austria. Sustainable Agriculture Research 1(2):308. https://doi.org/10.5539/sar.v1n2p308

Lee, J. M., A. J. Clark, and J. R. Roche. 2013. Climate-change effects and adaptation options for temperate pasture-based dairy farming systems: a review. Grass and Forage Science 68 (4):485-503. https://doi.org/10.1111/gfs. 12039

Leith, P., B. Jacobs, P. R. Brown, and R. Nelson. 2012. A participatory assessment of NRM capacity to inform policy and practice: cross-scale evaluation of enabling and constraining factors. Society and Natural Resources 25(8):775-793. https://doi. org/10.1080/08941920.2011.637548

Li, C., Y. Tang, H. Luo, B. Di, and L. Zhang. 2013. Local farmers' perceptions of climate change and local adaptive strategies: a case study from the Middle Yarlung Zangbo River Valley, Tibet, China. Environmental Management 52(4):894-906. https://doi. org/10.1007/s00267-013-0139-0

Liu, W. T. 2014. The application of resilience assessmentresilience of what, to what, with what? A case study based on Caledon, Ontario, Canada. Ecology and Society 19(4):21. https:// doi.org/10.5751/es-06843-190421

Liu, J., T. Dietz, S. R. Carpenter, M. Alberti, C. Folke, E. Moran, A. N. Pell, P. Deadman, T. Kratz, J. Lubchenco, E. Ostrom, Z. Ouyang, W. Provencher, C. L. Redman, S. H. Schneider, and W. W. Taylor. 2007. Complexity of coupled human and natural systems. Science 317(5844):1513-1516. https://doi.org/10.1126/ science. 1144004

Livestock Improvement Corporation Limited (LIC), DairyNZ Limited (DNZ). 2019. New Zealand dairy statistics 2018-2019. Livestock Improvement Corporation Limite, DairyNZ Limited, Hamilton, New Zealand. [online] URL: http://www.dairynz.co. nz/dairystatistics

Macdonald, K. A., D. Beca, J. W. Penno, J. A. S. Lancaster, and J. R. Roche. 2011. Short communication: effect of stocking rate on the economics of pasture-based dairy farms. Journal of Dairy Science 94(5):2581-2586. https://doi.org/10.3168/jds.2010-3688

Malone, E. L., and N. L. Engle. 2011. Evaluating regional vulnerability to climate change: purposes and methods. Wiley Interdisciplinary Reviews: Climate Change 2(3):462-474. https:// doi.org/10.1002/wcc.116

Mapfumo, P., S. Adjei-Nsiah, F. Mtambanengwe, R. Chikowo, and K. E. Giller. 2013. Participatory action research (PAR) as an entry point for supporting climate change adaptation by smallholder farmers in Africa. Environmental Development 5:6-22. https://doi.org/10.1016/j.envdev.2012.11.001

Marshall, N. A., and P. A. Marshall. 2007. Conceptualizing and operationalizing social resilience within commercial fisheries in northern Australia. Ecology and Society 12(1):1. https://doi. org/10.5751/ES-01940-120101

Meeske, R., and J. D. V. van Wyngaard. 2014. Replacing maize with palm kernel expeller in dairy concentrates fed to Jersey cows grazing kikuyu pasture. Pages 405-408 in 6th Australasian dairy science symposium proceedings, November 19-21, 2014, Hamilton, New Zealand. Australasian Dairy Science Symposium, Australia.

Meinke, H., S. M. Howden, P. C. Struik, R. Nelson, D. Rodriguez, and S. C. Chapman. 2009. Adaptation science for agriculture and natural resource management - urgency and theoretical basis. Current Opinion in Environmental Sustainability 1(1):69-76. https://doi.org/10.1016/j.cosust.2009.07.007 
Miller, F., H. Osbahr, E. Boyd, F. Thomalla, S. Bharwani, G. Ziervogel, B. Walker, J. Birkmann, S. van der Leeuw, J. Rockström, J. Hinkel, T. Downing, C. Folke, and D. Nelson. 2010. Resilience and vulnerability: complementary or conflicting concepts? Ecology and Society 15(3):11. https://doi.org/10.5751/es-03378-150311

Ministry for Primary Industries (MPI). 2015. Importation of palm kernel expeller from Indonesia: Indonesia visit, 8-13 March 2015: MPI audit report. Ministry for Primary Industries, Wellington, New Zealand. [online] URL: https://www.mpi.govt.nz/ dmsdocument/9165/direct

Ministry for Primary Industries (MPI) 2020. Ministry for Primary Industries annual report 2019/20. Ministry for Primary Industries, Wellington, New Zealand. [online] URL: https://www.mpi.govt. nz/dmsdocument/42448-201920-Annual-Report

Ministry for the Environment (MFE). 2018. Climate change projections for New Zealand: atmosphere projections based on simulations from the IPCC Fifth Assessment, 2nd Edition. Ministry for the Environment, Wellington, New Zealand. [online] URL: https://www.mfe.govt.nz/sites/default/files/media/Climate\%20Change/ Climate-change-projections-2nd-edition-final.pdf

Morad, M., and M. Jay. 1999. Conservation, market pressures and the New Zealand dairy sector. British Review of New Zealand Studies 12:45-54. [online] URL: https://researchcommons. waikato.ac.nz/bitstream/handle/10289/1456/convervation $\% 20$ market $\%$ 20pressures.pdf? sequence $=1 \&$ is Allowed $=\mathrm{y}$

Nayak, P. K., and F. Berkes. 2014. Linking global drivers with local and regional change: a social-ecological system approach in Chilika Lagoon, Bay of Bengal. Regional Environmental Change 14(6):2067-2078. https://doi.org/10.1007/s10113-012-0369-3

Naylor, A., J. Ford, T. Pearce, and J. van Alstine. 2020. Conceptualizing climate vulnerability in complex adaptive systems. One Earth 2(5):444-454.https://doi.org/10.1016/j. oneear.2020.04.011

Nelson, R., P. Kokic, S. Crimp, H. Meinke, and S. M. Howden. 2010 . The vulnerability of Australian rural communities to climate variability and change: part I - conceptualising and measuring vulnerability. Environmental Science and Policy 13 (1):8-17. https://doi.org/10.1016/j.envsci.2009.09.006

Nelson, R., P. Kokic, S. Crimp, P. Martin, H. Meinke, S. M. Howden, P. de Voil, and U. Nidumolu. 2010a. The vulnerability of Australian rural communities to climate variability and change: part II - integrating impacts with adaptive capacity. Environmental Science and Policy 13(1):18-27. https://doi. org/10.1016/j.envsci.2009.09.007

Nicholas, K. A., and W. H. Durham. 2012. Farm-scale adaptation and vulnerability to environmental stresses: insights from winegrowing in Northern California. Global Environmental Change 22(2):483-494. https://doi.org/10.1016/j.gloenvcha.2012.01.001

Niles, M. T., and N. D. Mueller. 2016. Farmer perceptions of climate change: associations with observed temperature and precipitation trends, irrigation, and climate beliefs. Global Environmental Change 39:133-142. https://doi.org/10.1016/j. gloenvcha.2016.05.002
Norris, F. H., S. P. Stevens, B. Pfefferbaum, K. F. Wyche, and R. L. Pfefferbaum. 2008. Community resilience as a metaphor, theory, set of capacities, and strategy for disaster readiness. American Journal of Community Psychology 41(1-2):127-150. https://doi.org/10.1007/s10464-007-9156-6

Olsson, L., A. Jerneck, H. Thoren, J. Persson, and D. O’Byrne. 2015. Why resilience is unappealing to social science: theoretical and empirical investigations of the scientific use of resilience. Science Advances 1(4):e1400217. https://doi.org/10.1126/sciadv.1400217

Parsons, M., and J. Nalau. 2016. Historical analogies as tools in understanding transformation. Global Environmental Change 38:82-96. https://doi.org/10.1016/j.gloenvcha.2016.01.010

Paton, D. 2006. Disaster resilience: integrating individual, community, institutional and environmental perspectives. Pages 306-319 in D. Paton and D. M. Johnston, editors. Disaster resilience: an integrated approach. Charles C. Thomas, Springfield, Illinois, USA.

Paton, D. 2013. Disaster resilient communities: developing and testing an all-hazards theory. Journal of Integrated Disaster Risk Management 3(1):17. https://doi.org/10.5595/idrim.2013.0050

Pearce, H. G., J. Kerr, A. Clark, B. Mullan, D. Ackerley, T. CareySmith, and E. Yang. 2011. Improved estimates of the effect of climate change on NZ fire danger. MAF Technical paper No: 2011/13. Ministry of Agriculture and Forestry, Wellington, New Zealand. [online] URL: https://www.mpi.govt.nz/dmsdocument/6214/ direct

Pomeroy, A. 2015. Resilience of family farming 1984-2014: case studies from two sheep/beef hill country districts of New Zealand. New Zealand Geographer 71(3):146-158. https://doi.org/10.1111/ $\underline{\text { nzg. } 12106}$

Preston, B. L., E. J. Yuen, and R. M. Westaway. 2011. Putting vulnerability to climate change on the map: a review of approaches, benefits, and risks. Sustainability Science 6 (2):177-202. https://doi.org/10.1007/s11625-011-0129-1

Pullar, W. A. 1985. Soils and land use of Rangitaiki Plains, North Island, New Zealand. N.Z. Soil Survey Report 86. Department of Scientific and Industrial Research, New Zealand.

Reisinger, A., R. L. Kitching, F. Chiew, L. Hughes, P. C. D. Newton, S. S. Schuster, A. Tait, and P. Whetton. 2014. Australasia. Pages 1371-1438 in V. R. Barros, C. B. Field, D. J. Dokken, M. D. Mastrandrea, K. J. Mach, T. E. Bilir, K. Chatterjee, K. L. Ebi, Y. O. Estrada, R. C. Genova, B. Girma, E. S. Kissel, A. N. Levy, S. MacCracken, P. R. Mastrandrea, and L. L. White, editors. Climate change 2014: impacts, adaptation and vulnerability. Part $B$ : regional aspects. Contribution of Working Group II to the Fifth Assessment Report of the Intergovernmental Panel on Climate Change. Cambridge University Press, Cambridge, United Kingdom and New York, New York, USA. https://doi. org/10.1017/cbo9781107415386.005

Revell, P., and C. Henderson. 2019. Operationalising a framework for understanding community resilience in Europe. Regional Environmental Change 19(4):967-979. https://doi.org/10.1007/ $\underline{\text { s10113-018-1390-y }}$ 
Rickards, L., and S. M. Howden. 2012. Transformational adaptation: agriculture and climate change. Crop and Pasture Science 63(3):240-250. https://doi.org/10.1071/CP11172

Rodima-Taylor, D. 2012. Social innovation and climate adaptation: local collective action in diversifying Tanzania. Applied Geography 33:128-134. https://doi.org/10.1016/j. apgeog.2011.10.005

Ross, H., and F. Berkes. 2014. Research approaches for understanding, enhancing, and monitoring community resilience. Society and Natural Resources 27(8):787-804. https://doi. org/10.1080/08941920.2014.905668

Rowarth, J. S. 2013. Dairy cows economic production and environmental protection. Pages 85-93 in J.R. Dymond, editor. Ecosystem services in New Zealand: conditions and trends. Manaaki Whenua Press, Lincoln, New Zealand..

Salinger, M. J., J. Renwick, E. Behrens, A. B. Mullan, H. J. Diamond, P. Sirguey, R. O. Smith, M. C. T. Trought, L. Alexander, N. J. Cullen, B. B. Fitzharris, C. D. Hepburn, A. K. Parker, and P. J. Sutton. 2019. The unprecedented coupled ocean-atmosphere summer heatwave in the New Zealand region 2017/18: drivers, mechanisms and impacts. Environmental Research Letters 14 (4):044023. https://doi.org/10.1088/1748-9326/ab012a

Schröter, D., C. Polsky, and A. G. Patt. 2005. Assessing vulnerabilities to the effects of global change: an eight step approach. Mitigation and Adaptation Strategies for Global Change 10(4):573-595. https://doi.org/10.1007/s11027-005-6135-9

Shadbolt, N. M., and F. Olubode-Awosola. 2016. Resilience, risk and entrepreneurship. International Food and Agribusiness Management Review 19(2):33-52. [online] URL: https://mro. massey.ac.nz/bitstream/handle/10179/9778/IFAMR\%20risk\% 20resillience $\% 20 \& \% 20$ entrepreneurship $\% 202016$.pdf? sequence $=1$

Shepherd, T. G. 2009. Visual soil assessment. Field guide for pastoral grazing and cropping on flat to rolling country. Volume 1. Second edition. Horizons Regional Council, Palmerston North, New Zealand. [online] URL: https://soils.landcareresearch.co.nz/ assets/Soil-reports/VSA-Vol1-compressed.pdf

Simmie, J., and R. Martin. 2010. The economic resilience of regions: towards an evolutionary approach. Cambridge Journal of Regions, Economy and Society 3(1):27-43. https://doi. org/10.1093/cjres/rsp029

Siegrist, M., and G. Cvetkovich. 2000. Perception of hazards: the role of social trust and knowledge. Risk Analysis 20(5):713-720. https://doi.org/10.1111/0272-4332.205064

Sinclair, K., A. Curtis, E. Mendham, and M. Mitchell. 2014. Can resilience thinking provide useful insights for those examining efforts to transform contemporary agriculture? Agriculture and Human Values 31(3):371-384. https://doi.org/10.1007/s10460-014-9488-4

Smit, B., and M. W. Skinner. 2002. Adaptation options in agriculture to climate change: a typology. Mitigation and Adaptation Strategies for Global Change 7(1):85-114. https://doi. org/10.1023/A:1015862228270
Smit, B., and J. Wandel. 2006. Adaptation, adaptive capacity and vulnerability. Global Environmental Change 16(3):282-292. https://doi.org/10.1016/j.gloenvcha.2006.03.008

Smith, W. 2019. Wairoa: resilience and change. Pages 46-59 in M. Brown, B. Kaye-Black, and P. Payne, editors. Heartland strong: how rural New Zealand can change and thrive. Massey University Press, Auckland, New Zealand.

Smith, W., C. Davies-Colley, A. Mackay, and G. Bankoff. 2011. Social impact of the 2004 Manawatu floods and the 'hollowing out' of rural New Zealand. Disasters 35(3):540-553. https://doi. org/10.1111/j.1467-7717.2011.01228.x

Spector, S., N. A. Cradock-Henry, S. Beaven, and C. Orchiston. 2019. Characterising rural resilience in Aotearoa-New Zealand: a systematic review. Regional Environmental Change 19 (2):543-557. https://doi.org/10.1007/s10113-018-1418-3

Stockdale, C. R. 1995. Maize silage as a supplement for pasturefed dairy cows in early and late lactation. Australian Journal of Experimental Agriculture 35(1):19-26. https://doi.org/10.1071/ $\underline{\text { EA9950019 }}$

Tanner, T., D. Lewis, D. Wrathall, R. Bronen, N. Cradock-Henry, S. Huq, C. Lawless, R. Nawrotzki, V. Prasad, M. A. Rahman, R. Alaniz, K. King, K. McNamara, M. Nadiruzzaman, S. HenlyShepard, and F. Thomalla. 2015. Livelihood resilience in the face of climate change. Nature Climate Change 5(1):23-26. https://doi. org/10.1038/nclimate2431

Turner, B. L., H. M. Menendez, R. Gates, L. O. Tedeschi, and A. S. Atzori. 2016. System dynamics modeling for agricultural and natural resource management issues: review of some past cases and forecasting future roles. Resources 5(4):40. https://doi. org/10.3390/resources5040040

van Apeldoorn, D. F., B. Kempen, M. P. W. Sonneveld, and K. Kok. 2013. Co-evolution of landscape patterns and agricultural intensification: an example of dairy farming in a traditional Dutch landscape. Agriculture, Ecosystems and Environment 172:16-23. https://doi.org/10.1016/j.agee.2013.04.002

van Wyngaard, J. D. V., and R. Meeske. 2017. Palm kernel expeller increases milk fat content when fed to grazing dairy cows. South African Journal of Animal Science 47(2):219-230. https://doi. org/10.4314/sajas.v47i2.14

Verkerk, G. 2003. Pasture-based dairying: challenges and rewards for New Zealand producers. Theriogenology 59(2):553-561. https://doi.org/10.1016/S0093-691X(02)01239-6

Walker, B. H., N. Abel, J. M. Anderies, and P. Ryan. 2009. Resilience, adaptability, and transformability in the GoulburnBroken Catchment, Australia. Ecology and Society 14(1):12. https://doi.org/10.5751/ES-02824-140112

Walker, B., C. S. Holling, S. R. Carpenter, and A. Kinzig. 2004. Resilience, adaptability and transformability in social-ecological systems. Ecology and Society 9(2):5. https://doi.org/10.5751/ ES-00650-090205

Walker, B. H., and D. Salt. 2012. Resilience practice: building capacity to absorb disturbance and maintain function. Island, Washington, D.C., USA. https://doi.org/10.5822/978-1-61091-231-0 
Yletyinen, J., P. Brown, R. Pech, D. Hodges, P. E. Hulme, T. F. Malcolm, F. J. F. Maseyk, D. A. Peltzer, G. L. W. Perry, S. J. Richardson, S. J. Smaill, M. C. Stanley, J. H. Todd, P. J. Walsh, W. Wright, and J. M. Tylianakis. 2019. Understanding and managing social-ecological tipping points in primary industries. BioScience 69(5):335-347. https://doi.org/10.1093/biosci/biz031 